\title{
Sedimentation History of Lago Loíza, Puerto Rico, 1953-94
}

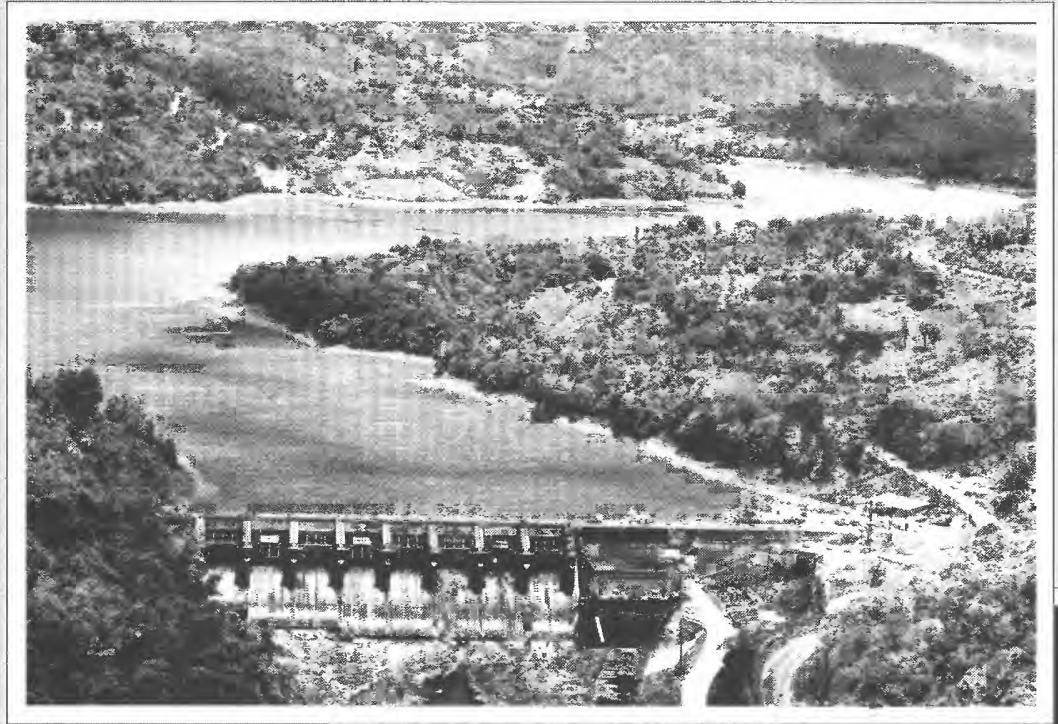

\section{U.S. GEOLOGICAL SURVEY}

Water-Resources Investigations Report 97-4108
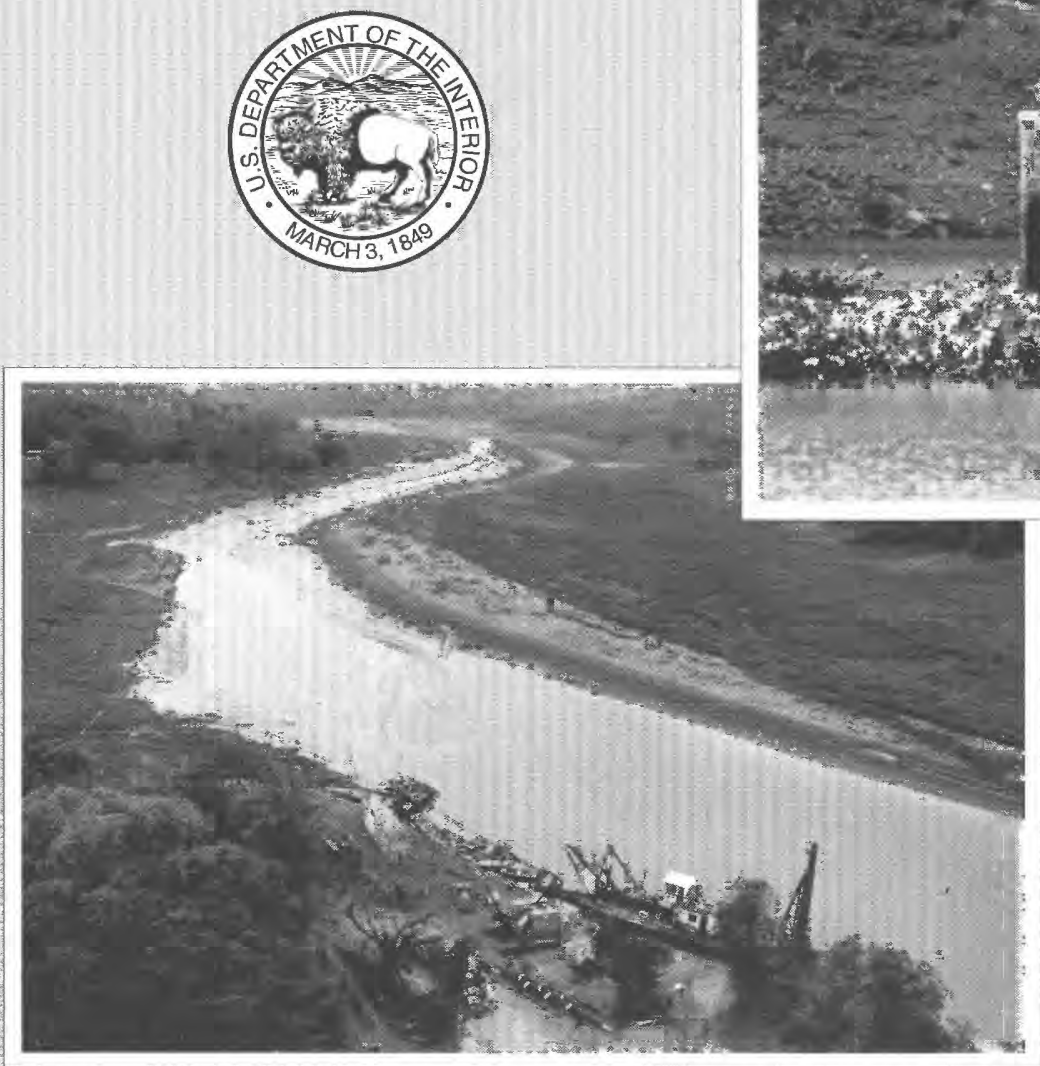

Prepared in cooperation with the PUERTO RICO AQUEDUCT AND SEWER AUTHORITY 


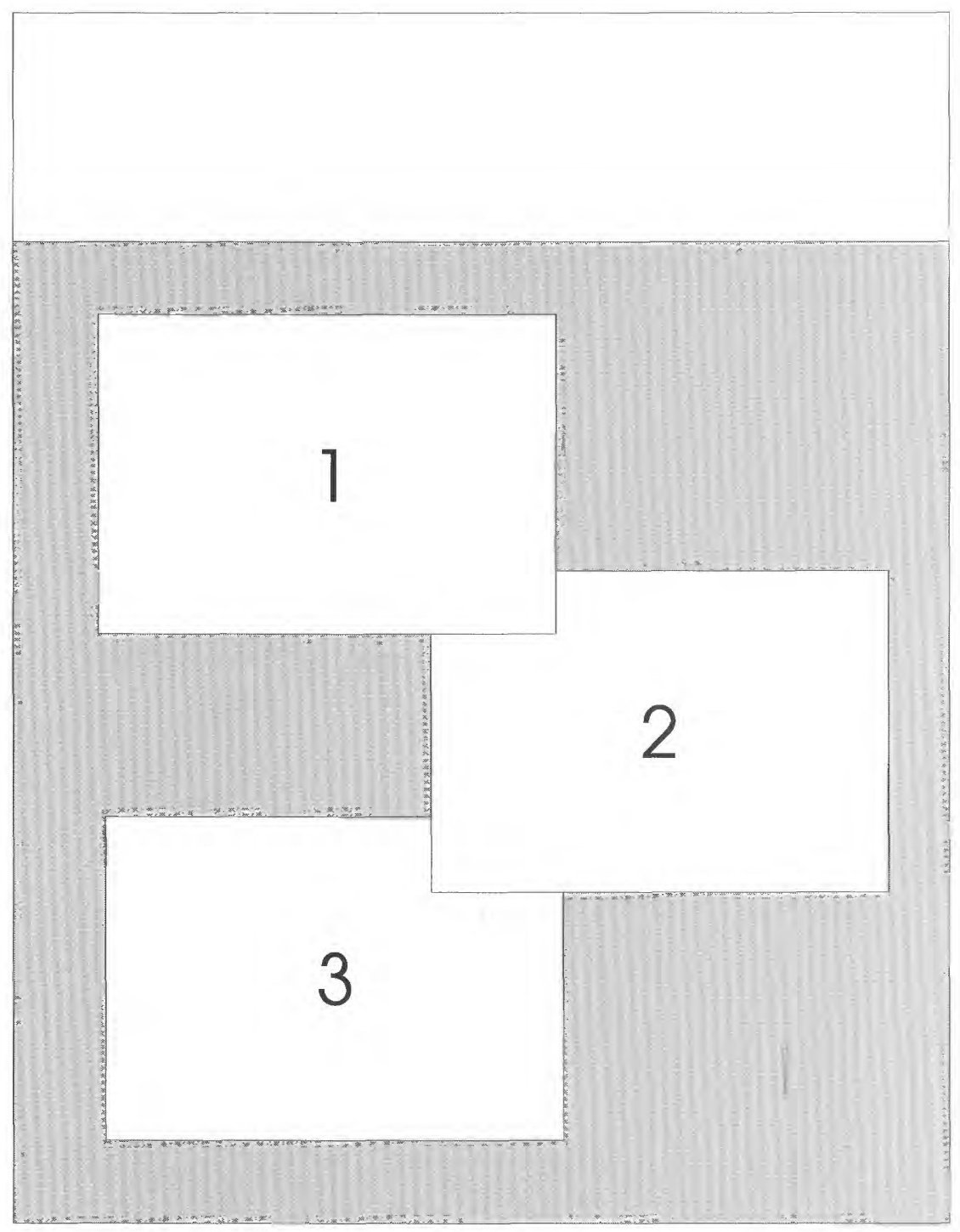

Photo 1. Dam

Aerial photograph looking south towards Carraízo Dam and Lago Loíza on May 12, 1994, during the early stages of the meteorological drought of 1994 -- pool elevation is 37.44 meters above mean sea level. Normal maximum pool elevation is 41.14 meters above mean sea level - Courtesy of EI Nuevo Día, Inc.

\section{Photo 2. House and Pelicans}

Photograph of a house built next to the Río Grande de Loíza before its impoundment, approximately 900 meters upstream of the eventual location of Carraízo Dam, August 12, 1994 -- pool elevation is 33.36 meters above mean sea level - Courtesy of El Nuevo Día, Inc.

\section{Photo 3. Dredging operations}

Photograph looking northeast from a vantage point approximately 5,000 meters upstream of Carraízo Dam, July 13, 1994. The dredging operations opened a small channel between two pools of water separated by sediments deposited in a broad section of the reservoir. At normal pool elevations, the reservoir extends from the tree line on the left bank of the lake to the tree line on the right bank -- pool elevation is 33.76 meters above mean sea level - Courtesy of El Nuevo Día, Inc. 


\section{Sedimentation History of Lago Loíza, Puerto Rico, 1953-94}

By Richard M.T. Webb and Luis R. Soler-López

U.S. GEOLOGICAL SURVEY

Water-Resources Investigations Report 97-4108

Prepared in cooperation with the PUERTO RICO AQUEDUCT AND SEWER AUTHORITY 


\section{U.S. DEPARTMENT OF THE INTERIOR \\ BRUCE BABBITT, Secretary}

\section{U.S. GEOLOGICAL SURVEY}

Gordon P. Eaton, Director

Use of trade names in this report is for identification purposes only and does not imply endorsement by the U.S. Government.

For additional information write to:

District Chief

U.S. Geological Survey

GSA Center, Suite 400-15

651 Federal Drive

Guaynabo, Puerto Rico 00965
Copies of this report can be purchased from:

U.S. Geological Survey

Branch of Information Services

Box 25286

Denver, CO 80225-0286 


\section{CONTENTS}

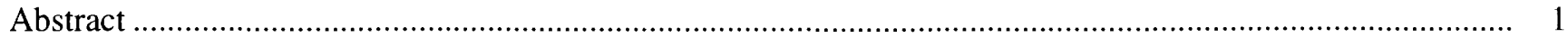

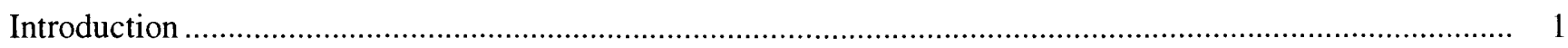

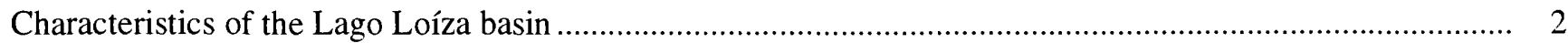

Characteristics of Carraízo Dam and Lago Loíza .............................................................................. 2

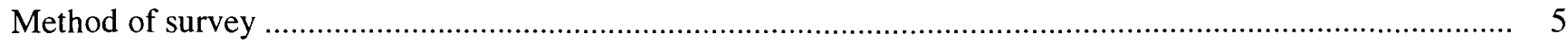

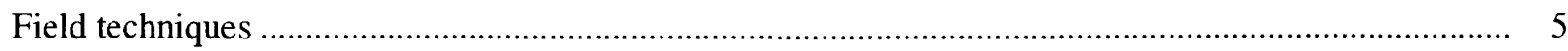

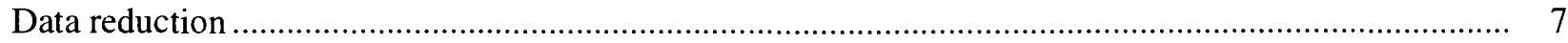

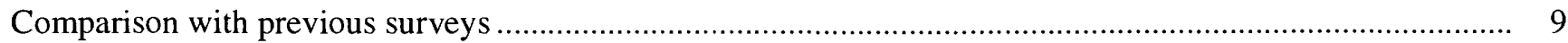

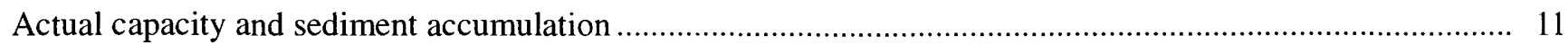

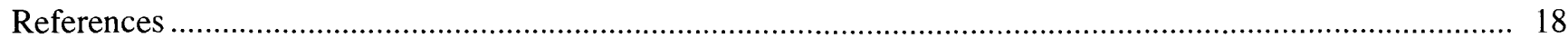

\section{PLATES}

[Plates are in pocket]

1. Lago Loíza, Puerto Rico, Bathymetry, 1994 (Northern Section)

2. Lago Loíza, Puerto Rico, Bathymetry, 1994 (Central Section)

3. Lago Loíza, Puerto Rico, Bathymetry, 1994 (Southern Section)

4. Lago Loíza, Puerto Rico, Topography, 1947 (Northern Section)

5. Lago Loíza, Puerto Rico, Topography, 1947 (Central Section)

6. Lago Loíza, Puerto Rico, Topography, 1947 (Southern Section)

7. Lago Loíza, Puerto Rico, Sediment Thickness, 1994 (Northern Section)

8. Lago Loíza, Puerto Rico, Sediment Thickness, 1994 (Central Section)

9. Lago Loíza, Puerto Rico, Sediment Thickness, 1994 (Southern Section) 


\section{FIGURES}

1.-3. Maps showing:

1. Location of Lago Loíza in the Río Grande de Loíza basin, Puerto Rico ........................................ 3

2. Track lines for 1994 bathymetric survey of Lago Loíza, Puerto Rico ......................................... 6

3. Reference distances for longitudinal sections of Lago Loíza, Puerto Rico, along the

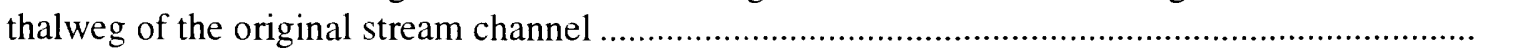

4. Graph showing historical longitudinal profiles of Lago Loíza, Puerto Rico, 1953-94 ....................... 12

5. Map of Lago Loíza, Puerto Rico, locating cross sections that have been surveyed both by the Soil Conservation Service and the U.S. Geological Survey, 1953-94

6.-8. Graphs showing:

6. Historical cross sections of Lago Loíza, Puerto Rico, 1953-94 ...................................................... 14

7. Stage-volume curves for Lago Loíza, Puerto Rico.................................................................... 16

8. Stage-area curves for Lago Loíza, Puerto Rico .................................................................... 16

9. Bar graph showing the volume of sediment deposited in Lago Loíza from 1953 to 1994, in 1-meter intervals

10. Graph showing the total volume of sediments accumulated in Lago Loíza above a given elevation from 1953 to 1994

\section{TABLES}

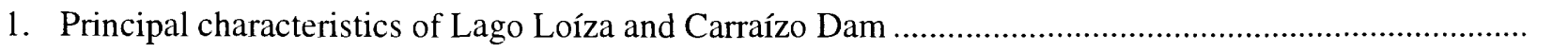

2. Comparison of prior and current sedimentation surveys of Lago Loíza, Puerto Rico ............................ 10 


\section{CONVERSION FACTORS AND ACRONYMS}

\begin{tabular}{rcl}
\hline Multiply & By & To obtain \\
\hline cubic meter $\left(\mathrm{m}^{3}\right)$ & 35.315 & cubic foot \\
cubic meter $\left(\mathrm{m}^{3}\right)$ & 264.17 & gallon \\
cubic meter $\left(\mathrm{m}^{3}\right)$ & 0.0008107 & acre-foot \\
cubic meter per second $\left(\mathrm{m}^{3} / \mathrm{s}\right)$ & 35.315 & cubic foot per second \\
cubic meter per second $\left(\mathrm{m}^{3} / \mathrm{s}\right)$ & 15850 & gallon per minute \\
cubic meter per second $\left(\mathrm{m}^{3} / \mathrm{s}\right)$ & 22.826 & million gallons per day \\
kilogram per square kilometer $\left(\mathrm{kg} / \mathrm{km}^{2}\right)$ & 0.002855 & ton per square mile \\
kilometer $\left(\mathrm{km}^{2}\right)$ & 0.62137 & mile \\
$\operatorname{meter}(\mathrm{m})$ & 3.2808 & foot \\
million cubic meters $\left(\mathrm{Mm}^{3}\right)$ & 810.71 & acre-foot \\
square kilometer $\left(\mathrm{km}^{2}\right)$ & 247.11 & acre \\
square kilometer $\left(\mathrm{km}^{2}\right)$ & 0.3861 & square mile \\
square meter $\left(\mathrm{m}^{2}\right)$ & 10.764 & square foot \\
\hline
\end{tabular}

Horizontal Datum - Puerto Rico Datum, 1940 Adjustment

Vertical Datum - National Geodetic Vertical Datum 1929 (NGVD29)

\section{ACRONYMS}

amsl above mean sea level

BLASS Bathymetric/Land Survey System

DGPS Differential Global Positioning System

GIS Geographic Information System

PRASA Puerto Rico Aqueduct and Sewer Authority

PRHTA Puerto Rico Highway and Transit Authority

TIN Triangulated Irregular Network

USGS U.S. Geological Survey 



\title{
Sedimentation History of Lago Loíza, Puerto Rico, 1953-94
}

\author{
By Richard M.T. Webb and Luis R. Soler-López
}

\section{Abstract}

A detailed bathymetric survey of Lago Loíza reservoir was conducted during November 1994 to calculate the actual storage capacity, sedimentation rate, trap efficiency, and sediment accumulation of the reservoir. The storage capacity of the reservoir in 1994 was 14.2 million cubic meters, equal to 53 percent of the original capacity of 26.8 million cubic meters when the dam was completed in 1953. The long-term sedimentation rate is about 303,000 cubic meters per year (about 1.1 percent of storage capacity loss per year). Sedimentation has been episodic, responding to major floods over the last 40 years; more than 3.6 million cubic meters of sediment were deposited during the 8 years from 1971 to 1979 while only 1.18 million cubic meters of sediment were deposited during the following 11 years from 1979 to 1990 . The reduced active storage capacity of the reservoir severely limits the continued utility of the reservoir as the principal water supply for the San Juan metropolitan area. Withdrawal by the Puerto Rico Aqueduct and Sewer Authority from the reservoir to the Sergio Cuevas filtration plant averages 4.4 cubic meters per second (100 million gallons per day). Although the average surface runoff amounts to more than four times the demand in a given year, the effective storage capacity is approximately one-tenth of the yearly demand.

\section{INTRODUCTION}

Lago Loíza is the main water supply for the San Juan metropolitan area, where more than one-quarter of Puerto Rico's population lives and works. The Puerto Rico Aqueduct and Sewer Authority (PRASA) had to implement strict rationing throughout Puerto Rico during the drought of 1993-94. The extent and severity of the rationing was exacerbated by the reduced storage capacity of Lago Loíza.

During 1994, the U.S. Geological Survey (USGS), in cooperation with the PRASA, conducted a study to determine the current storage capacity of Lago Loíza, determine rates of storage-capacity loss, and identify the location and thickness of sediments deposited in the reservoir. These data will be useful in estimating future sedimentation rates and to assist in evaluating options to restore the capacity of the reservoir. To accomplish these objectives, a bathymetric survey of Lago Loíza was conducted in November 1994. Data on position and water depth were acquired with a Differential Global Position System (DGPS) and a depth sounder and then directly stored in digital form. The digitized data were transferred into a Geographic Information System (GIS) for processing and analysis. The GIS was used to calculate storage volumes and sediment accumulation by comparing the 1994 topographic contour map with previous surveys, including a largescale 1947 topographic contour map produced before the Río Grande de Loíza was impounded in 1953. To provide additional temporal resolution, the data from 1947 and 1994 were compared with cross sections and volume calculations from lake surveys completed in 1963, 1971, 1979, and 1990. The comparisons and 
conclusions are presented in this report to document the volume and distribution of sediment deposited in Lago Loíza reservoir from its construction in 1953 through 1994.

\section{CHARACTERISTICS OF THE LAGO LOİZA BASIN}

The Río Grande de Loíza watershed is the largest drainage basin in Puerto Rico (fig. 1). The Carraízo Dam is the outlet for the upper Río Grande de Loíza drainage basin with an area of 538 square kilometers. The reservoir lies at the end of two flood plains formed by the Río Gurabo and the Río Grande de Loíza with alluvium covering almost 100 square kilometers of the basin. The largest city in the basin, Caguas, was established on the flood plain and is bounded by steeply sloped mountains composed of igneous and volcanic rock. Approximately 180 square kilometers of the upper Río Grande de Loíza basin is underlain by the San Lorenzo Batholith, composed of granodiorite that weathers readily into clays and course sands, approximately 130 square kilometers is underlain by volcanoclastic rocks, and 120 square kilometers is underlain by submarine basalts and cherts.

Mean annual rainfall within the upper Rio Grande de Loíza basin ranges from as much as 5,000 millimeters per year on the slopes of the Sierra de Luquillo mountains to about 1,600 millimeters per year in Juncos and Caguas which lie in the rain shadow of the mountain range (Calvesbert, 1970). The principal rivers draining into the reservoir are the Río Grande de Loíza, Río Gurabo, Río Cañas, and Río Bairoa. The combined mean annual discharge $(9.80$ cubic meters per second) of the Río Grande de Loíza and Río Gurabo constitute about 72 percent of the mean annual inflow to the reservoir. Assuming the same runoff rate for the rest of the basin, the long-term mean flow entering the reservoir is about 13.6 cubic meters per second. During periods when water is not being rationed, the average withdrawal for water use equals 4.4 cubic meters per second ( 100 million gallons per day). For water year 1994, the annual mean flow into Lago Loíza was 5.6 cubic meters per second; the seven-day minimum flow was 0.57 cubic meter per second for the Río Grande de Loíza and 0.16 cubic meter per second for the Río Gurabo (Díaz and others, 1995). While the average surface runoff amounts to more than three times the demand in a given year, the effective storage capacity is approximately one-tenth of the yearly demand.

The upper Río Grande de Loíza basin is one of the most highly developed watersheds in Puerto Rico with a population density of about 465 people per square kilometer (Department of Commerce, 1991). Within the basin are the towns of Aguas Buenas, Caguas, Gurabo, Juncos, Las Piedras, and San Lorenzo. Approximately 75 percent of the basin is steeply sloped with erodible soils (Iivari, 1981). Analysis of aerial photographs was used to determine that the agriculture land use accounted for 36 percent of the basin in 1950 but accounted for only 10 percent of the land use in 1987. Much of the cropland was abandoned and reverted to pasture and secondary forest during this period of time. The expected reduction in hillslope erosion resulting from the reversion to pasture and secondary forest has possibly been offset by increased erosion, due to construction activities as urban centers continue to expand in the Río Grande de Loíza drainage basin. Urban areas increased from 3 to 7 percent coverage of the basin from 1950 to 1987 (A. Gellis, USGS, personal commun., 1997).

\section{CHARACTERISTICS OF CARRAÍZO DAM AND LAGO LOİZA}

The Río Grande de Loíza was impounded in March of 1953 with the completion of the Carraízo Dam 21.7 kilometers upstream from the river's outlet to the Atlantic Ocean. The dam and reservoir characteristics are given in table 1 .

Lago Loíza was built to provide the San Juan metropolitan area with a municipal water supply. Although penstocks and turbines for power generation (3,000 kilowatts capacity) were originally included to provide an independent source of power for dam operations, hydroelectric power generation was later abandoned due to the infrequency of reservoir releases (Iivari, 1981). In 1977, flash boards were added to raise the maximum pool level from 40.14 meters above mean sea level (amsl) to 41.14 meters amsl. The additional storage capacity provided by the flash boards could be between 2.4 and 3.0 million cubic meters. The lower value is based on the 1994 bathymetry and the higher value on the 1947 topography. Sedimentation of small tributaries to the lake has reduced the surface area of the lake from 3.06 


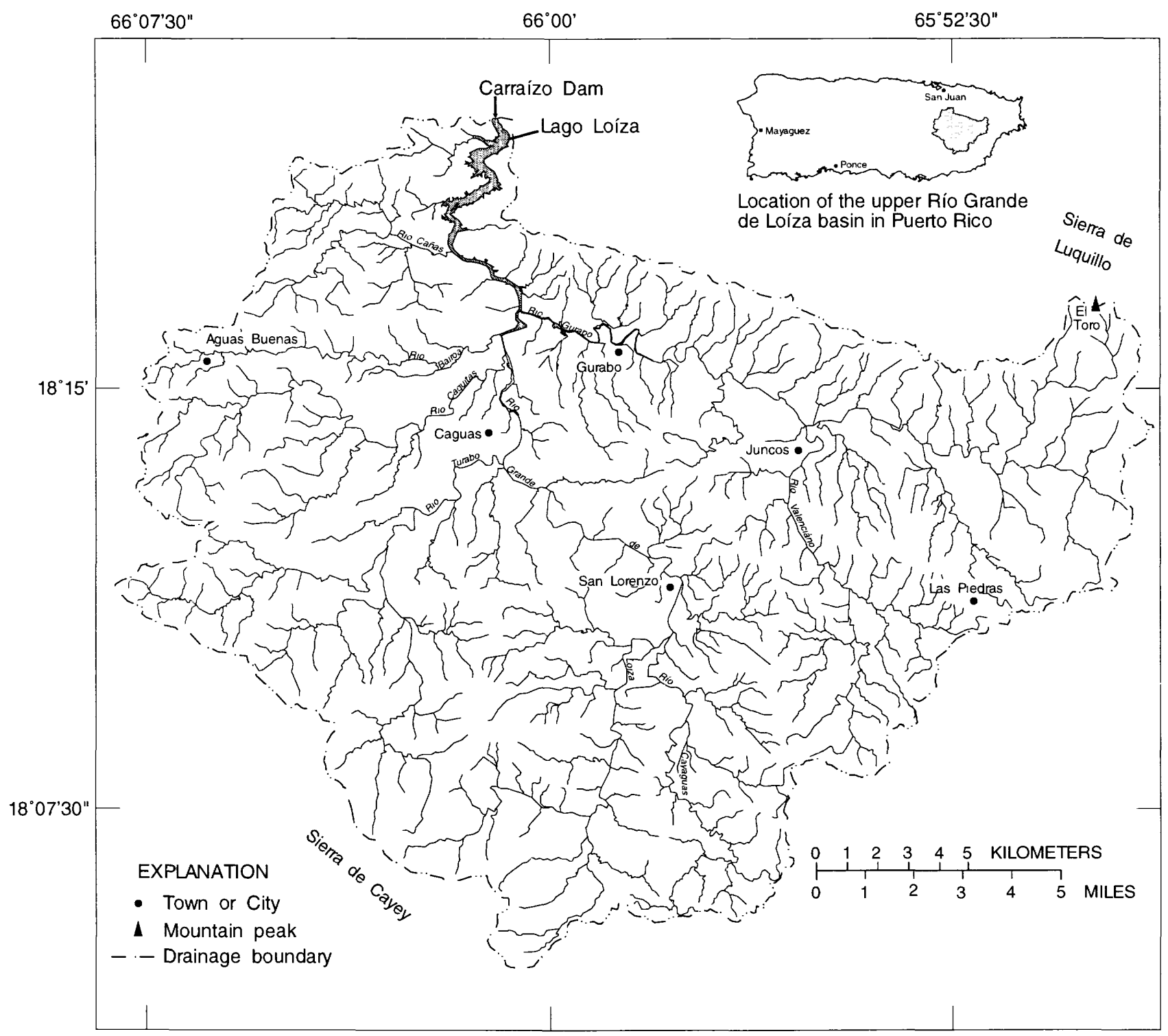

Figure 1. Location of Lago Loíza in the Río Grande de Loíza basin, Puerto Rico. 
Table 1. Principal characteristics of Lago Loíza and Carraízo Dam

[Modified from Sheda and Legas, 1968; and the Puerto Rico Electric Power Authority, 1980; amsl, above mean sea level; TIN, Triangulated Irregular Network]

Total length of dam at top (spillway and non-overflow sections) 210 meters

Length of spillway section 95.1 meters

Elevations: (amsl)

Top of dam 44.0 meters

Top of gates 41.14 meters

Spillway crest. 31.0 meters

Crown of lowest water intake 30.0 meters

Invert of intake structure 28.0 meters

Maximum width at base. 30.0 meters

Diameter of penstocks 1.67 meters

Installed power-generating capacity 3,000 kilowatts

Discharges with gates completely open

Maximum normal pool ( 41.14 meters amsl) 6,590 cubic meters per second

Maximum design elevation (43.0 meters amsl) 8,835 cubic meters per second

Top of dam (44.0 meters amsl) 9,970 cubic meters per second

Maximum discharge recorded at dam site (September 6, 1960) 4,814 cubic meters per second

Storage at pool elevation of 41.14 meters from 1947 TIN $26.80^{1}$ million cubic meters

Surcharge storage for flood control (from 41.14 to 43 meters) ${ }^{2}$ 8.0 million cubic meters

Drainage area at dam site 538 square kilometers

Design flooded area (elevation of 43 meters) Not available

Flooded area at 41.14 meters 2.67 square kilometers

Maximum pool elevation (top of gates). 41.14 meters

Maximum original depth of normal pool (pool elevation of 40.14 meters) 24 meters

Maximum depth during 1994 survey (pool elevation of 41.14 meters)..... 18 meters

Maximum length of normal pool ${ }^{3}$ 10 kilometers

\footnotetext{
${ }^{1}$ Hunt (1976) reported the original volume as 26.85 million cubic meters at a pool elevation of 40.14 meters amsl.

2 Assumes that the capacity between elevations of 41 and 44 meters above mean sea level has not changed since dam construction.

${ }^{3}$ To the confluence of the Río Grande de Loíza and the Río Gurabo, Puerto Rico.
} 
to 2.67 square kilometers from 1953 to 1994 (at a pool elevation of 41.14 meters amsl). Three 48 -inchdiameter silt sluice outlets in the overflow section of the dam (two at 22 meters and one at 17 meters amsl) were rendered inoperable in 1977 to prevent accidental discharges for the reservoir (Iivari, 1981).

\section{METHOD OF SURVEY}

The 1994 survey of Lago Loíza reservoir involved planning, data acquisition, and data processing. A geographic information system, Arc/Info ${ }^{1}$ was used to plan the survey lines and to analyze the bathymetric data. Bathymetric survey lines (track lines) were established at a spacing of 50 to 100 meters (fig. 2). Data describing the reservoir crosssections below the track lines were acquired with a Differential Global Positioning System (DGPS) combined with a depth sounder. The soundings were subsequently adjusted to represent depths below the maximum pool elevation (datum 41.14 meters above mean sea level). The corrected depths were then converted to elevations above mean sea level as established by the National Geodetic Vertical Datum 1929 (NGVD29). A bathymetric map ${ }^{2}$ of the reservoir bottom was constructed with elevation contours drawn at 1-meter intervals from the deepest part of the reservoir (26 meters amsl) up to the maximum pool elevation of 41 meters above mean sea level. The contour lines were then converted into a surface model of the reservoir bottom by creating a triangulated irregular network (TIN). The TIN represents the lake bottom as thousands of adjoining triangles with $\mathrm{x}, \mathrm{y}$, and $z$ coordinates assigned to all vertices. The volume of the reservoir was then calculated at incremental pool elevations. Cross sections and longitudinal sections were produced from the surface models. These sections were compared with the bathymetric data to verify that the model sections accurately reflect the reservoir bottom. To further describe the temporal

\footnotetext{
${ }^{1}$ Use of trade names in this report is for identification purposes only and does not imply endorsement by the U.S. Government.

${ }^{2}$ For purposes of this report, the topographic map describing elevations of the lake bottom after impoundment will be referred to as a bathymetric map to convey the fact that the surveyed area is below water. A strict interpretation of the word bathymetry would require that the contours be isobaths, or lines of equal depth, rather than lines of equal elevation.
}

variation in scour and fill in Lago Loíza since its impoundment, cross sections and longitudinal sections from surveys made in 1953, 1963, 1971, 1979, 1990, and 1994 are also presented. Finally, TINs created from the original reservoir bottom (from a 1:2000 scale topographic survey conducted prior to the impoundment) and the 1994 reservoir bottom were converted into geographically-registered grids with a 10 -meter cell spacing. The difference in elevation between the two surveys for each cell was determined and used to construct a map showing the net amount of deposition or erosion in different areas of the reservoir since its impoundment.

\section{Field Techniques}

The bathymetric survey of Lago Loíza was conducted from November 1 to 15, 1994. Data were collected with the Bathymetric/Land Survey System (BLASS) developed by Specialty Devices Inc. The system uses two Motorola SixGun differential geographic positioning systems (DGPS) for horizontal positioning. The GPS units were first used in static survey mode to establish reference marks at sites near the reservoir. A reference station, CARRAIZO $\left(18^{\circ} 19^{\prime} 40.7498^{\prime \prime} \mathrm{N}, 66^{\circ} 00^{\prime} 58.106^{\prime \prime} \mathrm{W}, 44.0\right.$ meters amsl), was established at the center of the dam using the USGS Benchmark MESAS (18 16'19.148"N, $66^{\circ} 03^{\prime} 13.408^{\prime \prime} \mathrm{W}, 344.96$ meters amsl). Because of the sinuous form of the reservoir, three additional reference stations were established. USGS benchmark SILLA $\left(18^{\circ} 18^{\prime} 15.410^{\prime \prime} \mathrm{N}, 65^{\circ} 59^{\prime} 16.219^{\prime \prime} \mathrm{W}, 366.73\right.$ meters amsl) was used as the master station to establish reference stations at MARINA $\left(18^{\circ} 17^{\prime} 43.36^{\prime \prime} \mathrm{N}, 66^{\circ} 00^{\prime} 37.60^{\prime \prime} \mathrm{W}, 317.0\right.$ meters amsl), TANQUE $\left(18^{\circ} 17^{\prime} 58.45^{\prime \prime} \mathrm{N}, 66^{\circ} 00^{\prime} 32.62^{\prime \prime} \mathrm{W}, 336.9\right.$ meters amsl), and PAPA JUAN (18 $17^{\circ} 57.54^{\prime \prime} \mathrm{N}$, $66^{\circ} 00^{\prime} 48.56^{\prime \prime} \mathrm{W}, 300.2$ meters amsl).

During the bathymetric survey, the reference station with the best visibility of the area to be surveyed was occupied as the master station to transmit GPS pseudorange corrections to the survey boat below. The GPS on board the survey boat independently calculated a position every second using the six satellites in view with the best geometry. Once every 5 seconds, the boat's GPS received a set of pseudorange corrections to maintain a positional accuracy of better than 2 meters. 


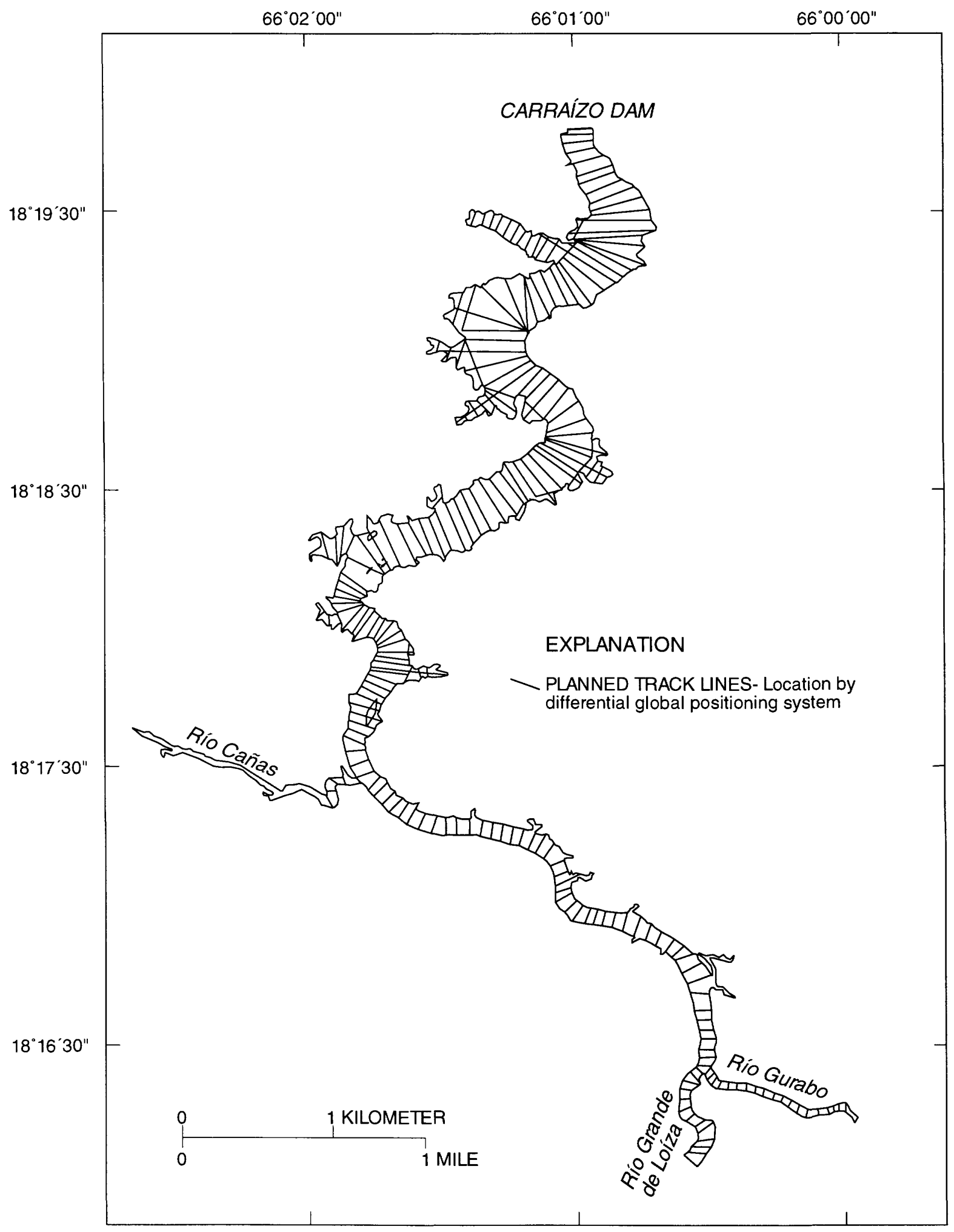

Figure 2. Track lines for 1994 bathymetric survey of Lago Loíza, Puerto Rico. 
Reservoir depths were measured using a SITEX LCS-200 echo sounder with a $200 \mathrm{kHz}$ transducer with a $9^{\circ}$ beam width. The echo sounder measured the depth to 0.1 meter and was calibrated in water depths of 3 and 10 meters. The bathymetric survey software HYPACK recorded the positions and depths once every second while in survey mode (equivalent to approximately one data point every 1.5 meters along the track line). HYPACK runs on a portable personal computer and is used both to record data and to navigate. The helmsman of the survey boat is provided with a graphical display showing the lake shore, the planned track lines, the actual position of the vessel while underway, and indicators of speed and the amount of deviation from the planned track lines.

Originally, 232 cross sections spaced from 50 to 100 meters apart were planned. However, sedimentation has filled many of the tributaries so bathymetric data could be obtained for only 217 cross sections. The minimum pool elevation during the survey was 40.84 meters amsl and the maximum pool elevation was 41.09 meters amsl. Where water hyacinths obstructed navigation, data were collected as far inland as possible and the depths were estimated for the remainder of the area. Through the years, sediments have deposited forming a broad spit extending out into the reservoir at a distance of 4.7 kilometers upstream of the dam. The spit was excavated by earth moving equipment while the pool elevation was below 36 meters amsl in spring and summer 1994. By November 1994, the reservoir level had risen to its maximum pool elevation, and only four small islands remained where the pre-excavation spit was located. Additional data were collected during the survey to document the locations of these and other islands in the reservoir. A channel was also dredged in the shallow area between 3.2 and 4.5 kilometers upstream of the dam, again during the low pool elevations of 1994. The narrow channel connected two water bodies isolated during the low stage so that flows across the shoal would not scour the sediments and degrade the quality of the water pumped to the filtration plant.

Bathymetric data were obtained from the Carraízo Dam upstream to the confluence of the Río Grande de Loíza and the Río Gurabo (9.9 kilometers) and approximately 800 meters upstream into the Río Grande de Loíza branch and approximately 1,000 meters upstream into the Río Gurabo branch (fig. 2). Longitudinal distances in meters from the dam were determined along the thalweg of the river as it appeared in the 1947 topography (fig. 3).

Random errors in positional data could occur because of GPS calculation errors; errors in depth data could occur because of bubbles on the transducer face or insufficient signal gain. Physical or electronic problems encountered in the field were corrected as soon as they were detected. If the amount of missing or erroneous data extended more than 20 meters, that cross section was rerun. If the amount of missing or erroneous data occurred for less than 20 meters along the cross section, and the bottom was flat or exhibited no change in slope before and after the section in which the data was lost, that section was not rerun but the data file was flagged for later editing.

\section{Data Reduction}

Initial editing and verification of the positional and depth data to eliminate obvious anomalies was performed within the HYPACK program. Spikes or jumps in the positional data may occur when a satellite "view" is obstructed by local topographic features or communications are disrupted by electromagnetic interference. In such instances, the location of the sounding may be erroneously calculated several hundred meters from the calculated position 1 second before or 1 second after it. In these cases, the erroneous positions were interpolated back to the midpoints between the antecedent and posterior positions. Elevated land surfaces between the boat and the master station may block the correction signal for an extended period of time. Whenever this occurred in Lago Loíza, the master station was relocated to one of the alternate reference stations and the survey was continued.

The pool elevation during the 1994 bathymetric survey ranged from 40.84 to 41.09 meters amsl, very close to the maximum pool elevation of 41.14 meters amsl. Reservoir water level was recorded every 15 minutes at the existing reservoir stage station at the dam (USGS station number 50059000). For each line, the recorded depths were subtracted from the observed reservoir stage to convert the soundings to elevations in meters amsl. The stage corrected data were then exported into a GIS.

The reservoir bottom was modeled and storage capacity estimated using a GIS. Using the individual soundings (almost 35,000 data points) contour lines 


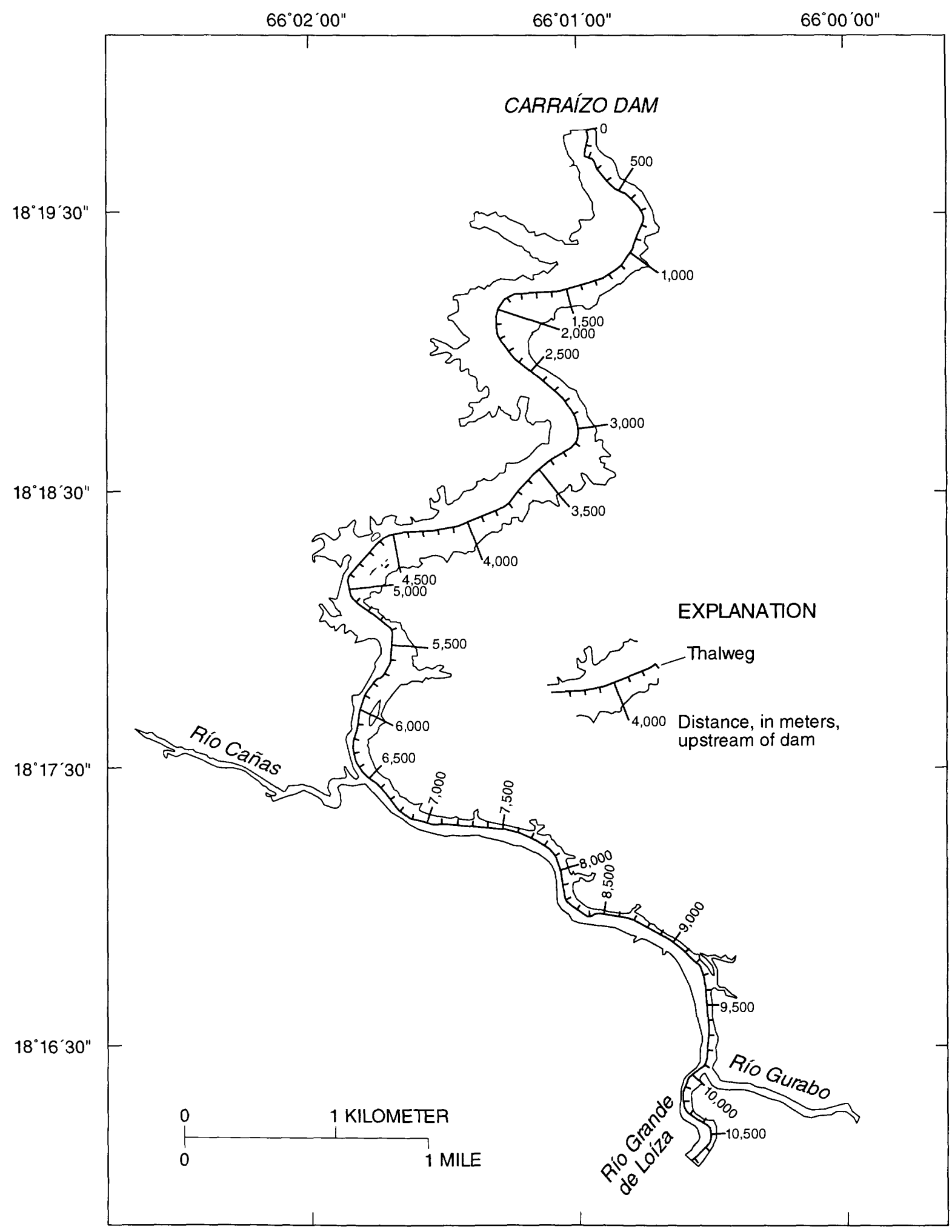

Figure 3. Reference distances (in meters) for longitudinal sections of Lago Loíza, Puerto Rico, along the thalweg of the original stream channel. 
were drawn at 1-meter intervals and a map produced at a scale of 1:5000 (pls. 1, 2, 3). The contour map was used to create a TIN. Stage-storage relationships were then calculated using the TIN as the surface model. The VOLUME algorithm (Environmental Systems Research Institute, Inc., 1992) integrates the volume between the surface model (TIN) and a given datum.

The topographic survey made in 1947 (prior to completion of the Carraízo Dam in 1953) was used in this study as the original reservoir bottom. Changes in the topography between 1947 and 1953, when the dam was completed, are assumed to be minimal. The 1947 topographic survey was produced at a scale of 1:2000 with a contour interval of 2 meters. The maximum elevation of the topographic survey was 44 meters amsl, though only the information up to and including the 42-meter contour will be used in this report. The contour lines were digitized in the GIS and a map produced at a scale of 1:5000 (pls. 4, 5, 6). These contour lines were then used to produce a TIN that was used for volume calculations and comparisons with the 1994 TIN.

The overall match between the original 1947 topography and 1994 reservoir bottom is satisfactory for documenting the total volume and location of sediment accumulated in the lake. However, differences exist between the hypothetical shoreline as defined by the 42-meter elevation contour on the 1947 topographic map and that defined by the 1994 bathymetric map. The shoreline for the 1994 bathymetry was modified from that shown on the Aguas Buenas quadrangle (1:20,000). The modified shoreline incorporated all valid GPS positions (horizontal accuracy better than 2 meters in most cases) to correct shoreline positions from the quadrangle (horizontal accuracy 40 meters). Still, the shoreline (using the 42-meter elevation contour) prior to impoundment was more accurate overall and the higher resolution can be appreciated in the maps (pls. $4,5,6)$. Highly irregular shorelines in the 1947 topographic map appear as smooth lines in the lower resolution modified quadrangle shoreline. However, independent of the higher resolution, the surface area of the reservoir at a pool elevation of 41.14 decreased from 3.06 square kilometers as determined using the 1947 topographic map scale to 2.67 square kilometers determined from the modified quadrangle map reflecting the complete siltation of many of the drowned tributaries.

\section{COMPARISON WITH PREVIOUS SURVEYS}

Twenty-five monumented cross sections were established in 1963 to correspond to cross sections measured before the dam impoundment (R.A. Guzmán, written commun., PRASA, 1963). This same set of cross sections were resurveyed in 1971 (Hunt, 1976) and 1979 (Iivari, 1981), although some cross sections had to be abandoned because of siltation. These surveys used a cable stretched between recovered monuments on both sides of the reservoir and, therefore, are comparable. The storage capacity and sediment volume were computed using the Dobson Modified Prismoidal formula where the cross sections were essentially parallel and by the Average End Area method where subsequent cross sections were excessively skewed (Iivari, 1981). Blanton (1982) gives an overview of standard methods used to calculate reservoir volumes.

The number of cross sections was increased to 69 in the bathymetric surveys of 1985 (Quiñones and others, 1989) and 1990 (L. Soler, USGS, unpublished data, 1990). Low resolution in both the horizontal and vertical dimensions resulted in an underestimate of the 1985 volume (12.46 million cubic meters) and so the results will not be used in the comparisons presented here. The 1990 survey collected high quality data on the same lines established in 1985. A precision flow meter was used to mark distances on the fathometer strip while navigating across the transect. A subset of the 1990 data was used by Gregory L. Morris \& Associates (1992) to calculate the 1990 volume of the reservoir. The sections that were in common with the 1953 survey were used and the Average End Area method used exclusively to calculate volumes for both 1953 and 1990 . Volume calculations can vary up to 10 percent for small reservoirs depending on the method and the quantity and orientation of the cross sections (Heinemann and Dvorak, 1963). However, where identical cross sections and volume calculation techniques are used, the bias should be consistent.

Previous volume calculations have been standardized to match the volume of the 1953 original reservoir bottom calculated using the TIN created here (table 2). The volumes reported by Iivari (1981) for 1953, 1963, 1971, and 1979 all used the same cross sections and volume calculation method; the volumes reported for these surveys were decreased by 10.1 
Table 2. Comparison of prior and current sedimentation surveys of Lago Loíza, Puerto Rico

[Volumes for 1953 and 1994 calculated with TIN developed in a GIS. Volumes for all other years were standardized so that the 1953 volumes matched that calculated in this report. All rates use the 1953 volume unless otherwise indicated. Elevation datum National Geodetic Vertical Datum 1929; —, no data available or undetermined]

\begin{tabular}{|c|c|c|c|c|c|c|}
\hline & 1953 & 1963 & 1971 & 1979 & 1990 & 1994 \\
\hline $\begin{array}{l}\text { Capacity (million cubic meters at } 41.14 \\
\text { meters amsl) }\end{array}$ & 26.80 & 23.41 & 20.00 & 16.38 & 15.2 & 14.19 \\
\hline $\begin{array}{l}\text { Live storage (above floor of intake } \\
\text { structure at } 28 \text { meters amsl) }\end{array}$ & 23.01 & - & - & - & - & 14.15 \\
\hline Dead storage (below 28 meters amsl) & 3.79 & - & - & - & - & 0.04 \\
\hline $\begin{array}{l}\text { Years since construction } \\
\text { (since March 1953) }\end{array}$ & 0 & 10.5 & 18.75 & 26.75 & 37.5 & 41.67 \\
\hline $\begin{array}{l}\text { Sediment accumulated } \\
\text { (million cubic meters) }\end{array}$ & 0 & 3.39 & 6.8 & 10.42 & 11.6 & 12.61 \\
\hline Storage loss (percent) & 0 & 12.65 & 25.37 & 38.88 & 43.28 & 47.05 \\
\hline $\begin{array}{l}\text { Rate of storage loss since construction } \\
\text { (cubic meters per year) }\end{array}$ & - & 323,000 & 362,000 & 390,000 & 309,000 & 303,000 \\
\hline $\begin{array}{l}\text { Rate of storage loss since previous } \\
\text { survey (cubic meters per year) }\end{array}$ & - & 323.000 & 413,000 & 452,000 & 110,000 & 242,000 \\
\hline Annual loss of capacity (percent) & - & 1.20 & 1.35 & 1.45 & 1.15 & 1.13 \\
\hline $\begin{array}{l}\text { Average sediment yield from basin } \\
\text { (megagrams per square kilometer per } \\
\text { year })^{1}\end{array}$ & - & 800 & 900 & 965 & 765 & 750 \\
\hline $\begin{array}{l}\text { Sediment yield from basin since previous } \\
\text { survey (megagrams per square kilometer } \\
\text { per year) }\end{array}$ & - & 800 & 1,025 & 1,120 & 270 & 600 \\
\hline Year that reservoir would fill ${ }^{2}$ & - & 2036 & 2027 & 2022 & 2040 & 2042 \\
\hline
\end{tabular}

${ }^{1}$ Assuming a long-term trapping efficiency of 75 percent and a sediment density of $1 \mathrm{~g} / \mathrm{cm}^{3}$.

2 Assuming that the reservoir would continue filling at the long-term sedimentation rate; in reality the reservoir sedimentation rate decreases with time as the reservoir fills and the trapping efficiency decreases. Also, the design of the tainter gates makes it impossible for the dam to fill completely as high bottom velocities can be expected in the several hundred meters upstream of the dam whenever the tainter gates are opened. 
percent. The 1953 and 1990 volumes calculated by Gregory L. Morris \& Associates (1992) used a consistent methodology: these volumes were increased by 5.5 percent, again to standardize the 1953 volume to match that calculated in this study.

The adjusted volumes and sedimentation calculations are consistent with the changes observed in the cross sections surveyed in 1953, 1963, 1971, 1979, 1990, and the current 1994 profiles. The deepest points of the cross sections were used to generate longitudinal sections for each year. The cross sections and the longitudinal sections graphically display how the southern section of the reservoir, upstream of the Río Cañas, quickly reached a new channel equilibrium. Within the first 10 years (1953 to 1963), from 1 to 3 meters of sediment accumulated, after which no further net deposition occurred as sediments would be transported through this shallow section to be deposited in the deeper sections further downstream.

Approximately 54 percent of the total sediments deposited in the reservoir were deposited in the 18-year period from 1953 to 1971 . As seen in the longitudinal profiles and the cross sections (figs. 4, 5, 6 ), sediments continue to deposit at rates up to 0.4 meter of sediment per year in areas where the reservoir broadens (such as sections 21 and 28). Section 28 indicates that the line for 1990 may have been improperly located at that site, because water depths shown in the 1990 profile are typical of sections a couple hundred meters upstream.

The spatial distribution of sediments is irregular, responding primarily to the hydraulics imposed by the reservoir morphology and gate operations. As much as 14 meters of sediment has deposited over the original reservoir bottom in the area of the original channel. The bulk of the deposits are found between 1 and 7 kilometers upstream of the dam, although narrow sections and submerged hills within that area have experienced minimal deposition (pls. 6-9).

\section{ACTUAL CAPACITY AND SEDIMENT ACCUMULATION}

The current capacity of Lago Loíza reservoir was computed to be 14.19 million cubic meters. This represents a loss of 47 percent of the volume as computed in this study from the 1947 topographic map at a scale of 1:2,000. The stage-area and stage-storage curves were produced for both the 1947 and the 1994 surface models (figs. 7, 8). Areas and volumes were calculated at 1 -meter intervals for each TIN. The bulk accumulation of the sediments have deposited above 30 meters elevation (fig. 9). The asymmetry of the curve reflects the large volumes of sediment deposited on the broad banks of the original flood plain that is not readily discernible from the longitudinal profiles. The graph is skewed reflecting the volume lost to the infilling of tributary streams in the shallower sections of the reservoir. The cumulative amount of sediment deposited above each elevation is presented in figure 10. Using the cumulative curve it can be determined that almost 11 million cubic meters of material would need to be dredged if all sediments deposited above 25 meters amsl were removed. 


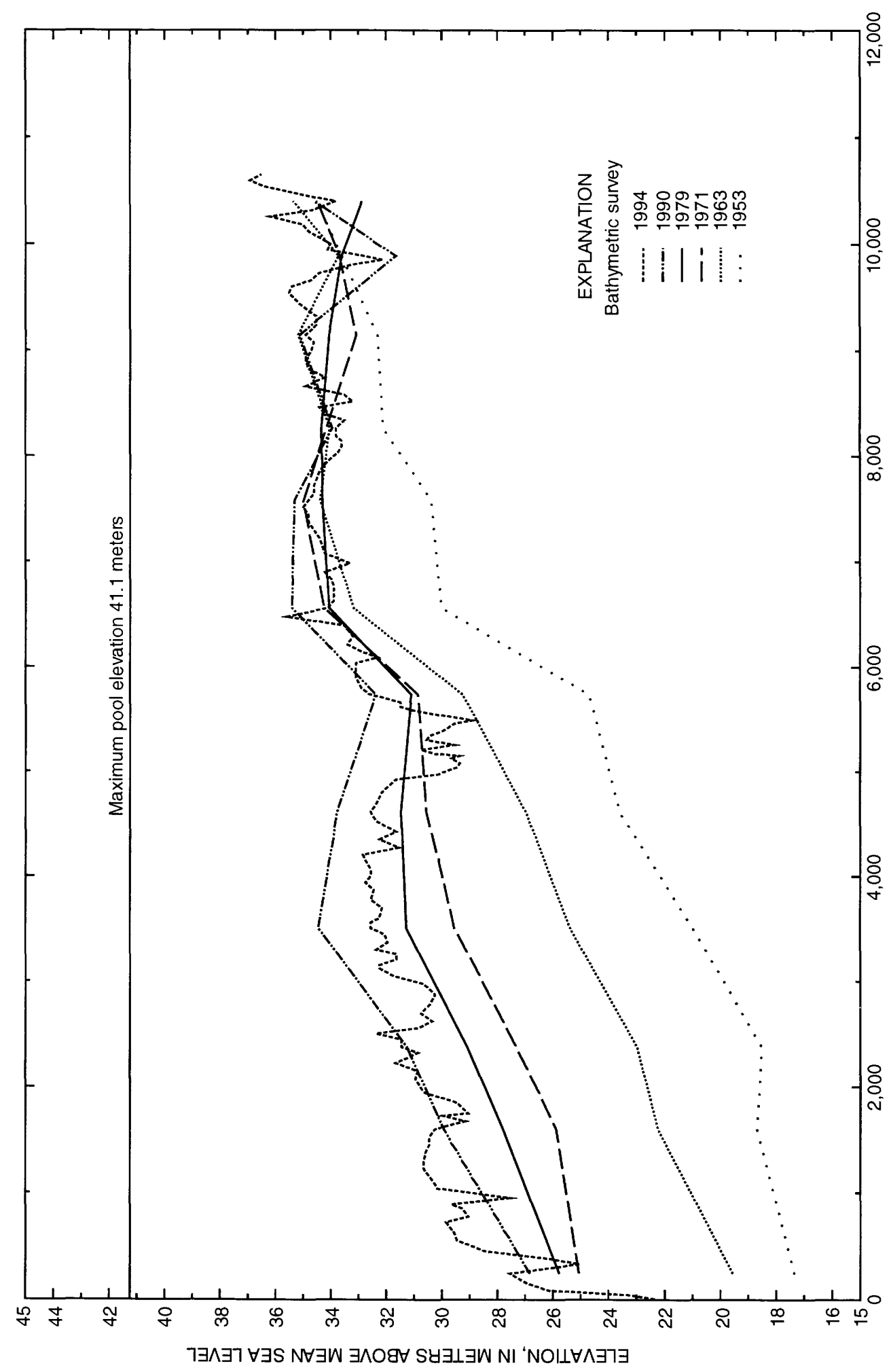

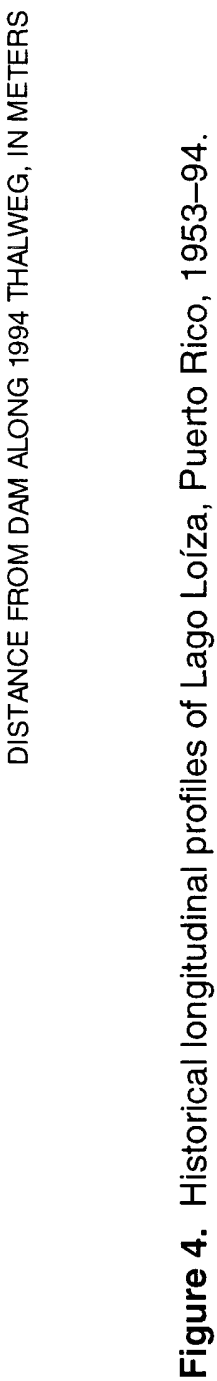




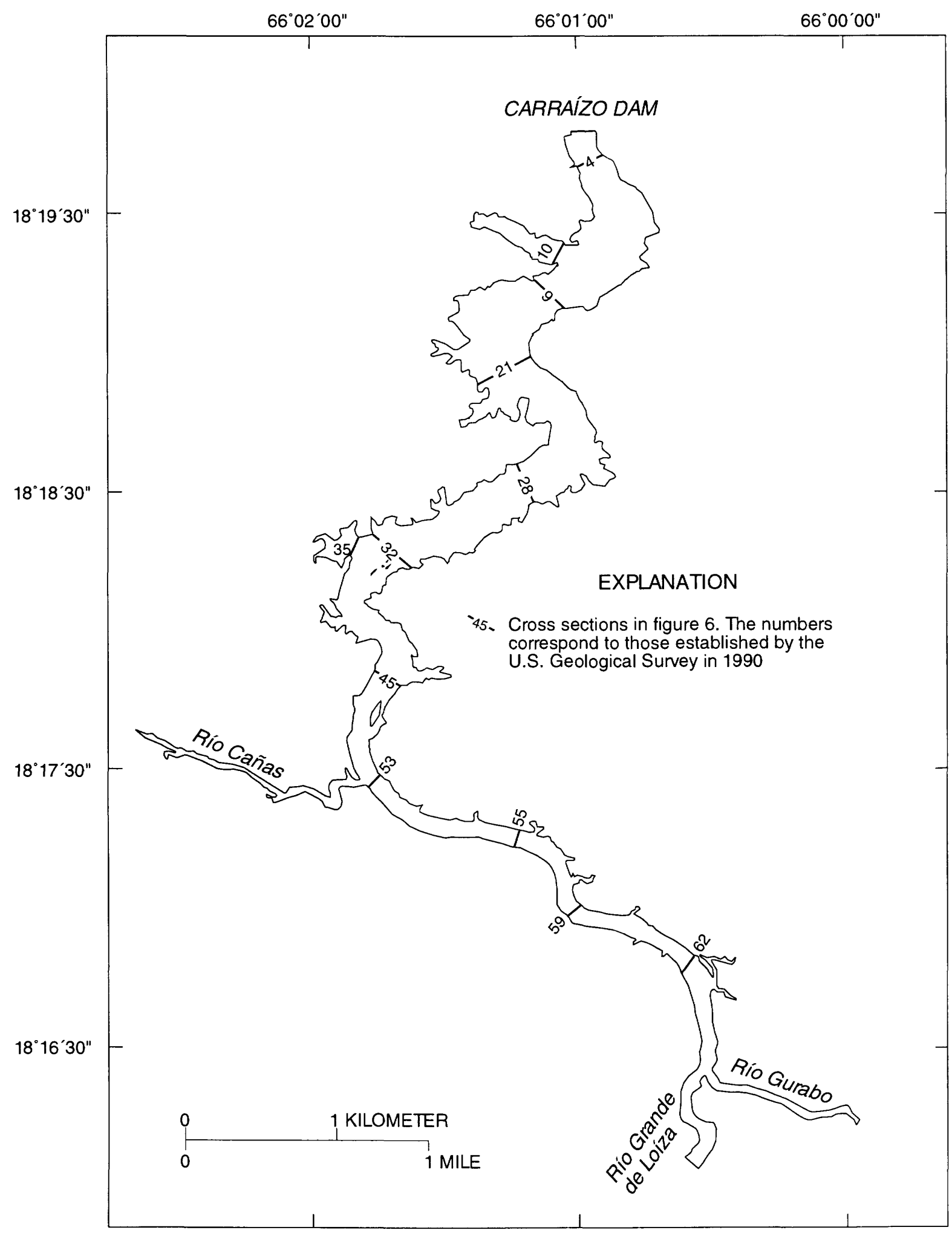

Figure 5. Map of Lago Loíza, Puerto Rico, locating cross sections that have been surveyed both by the Soil Conservation Service and the U.S. Geological Survey, 1953-94. 


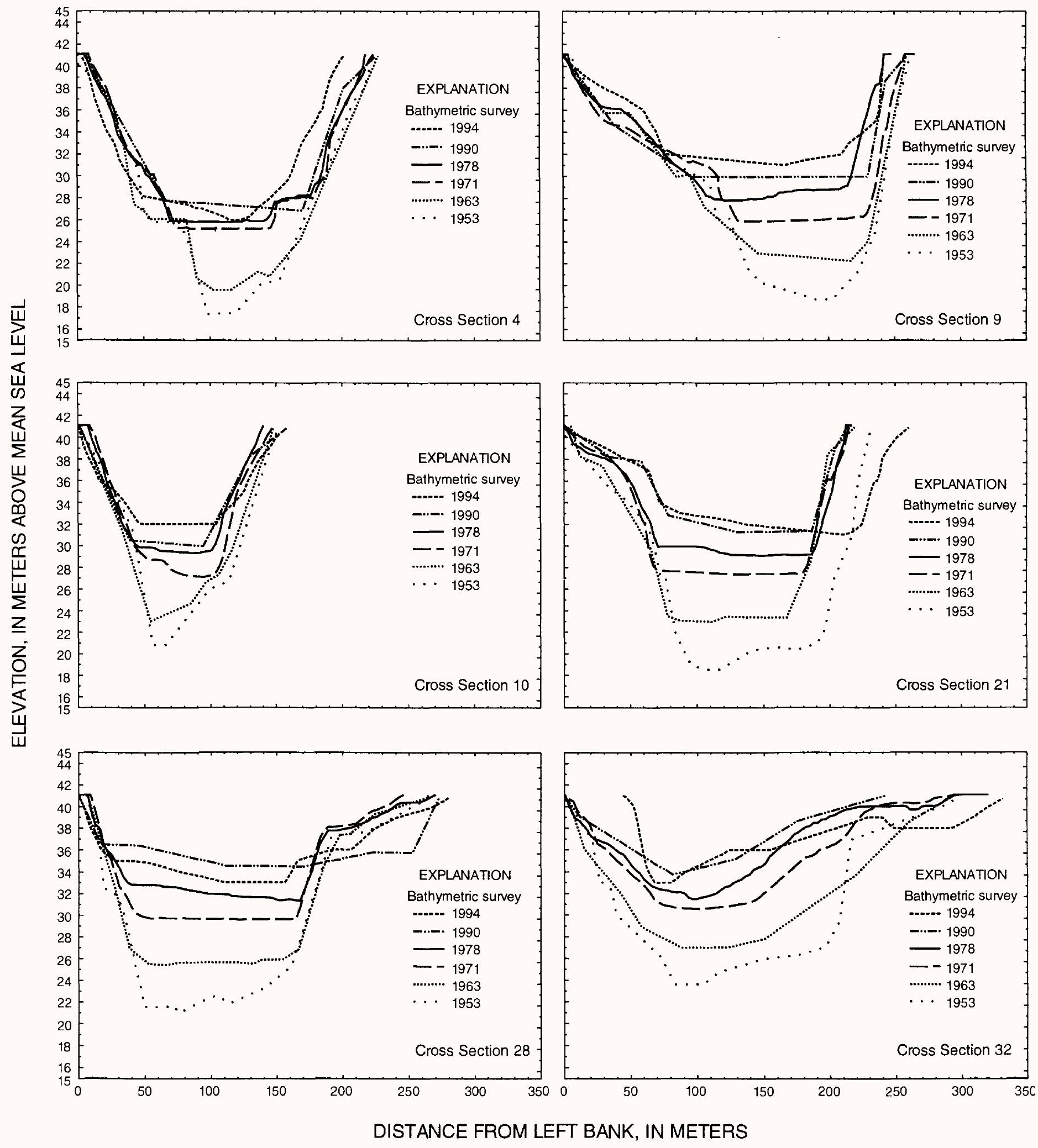

Figure 6. Historical cross sections of Lago Loíza, Puerto Rico, 1953-94. Locations of cross sections shown on figure 5 . 


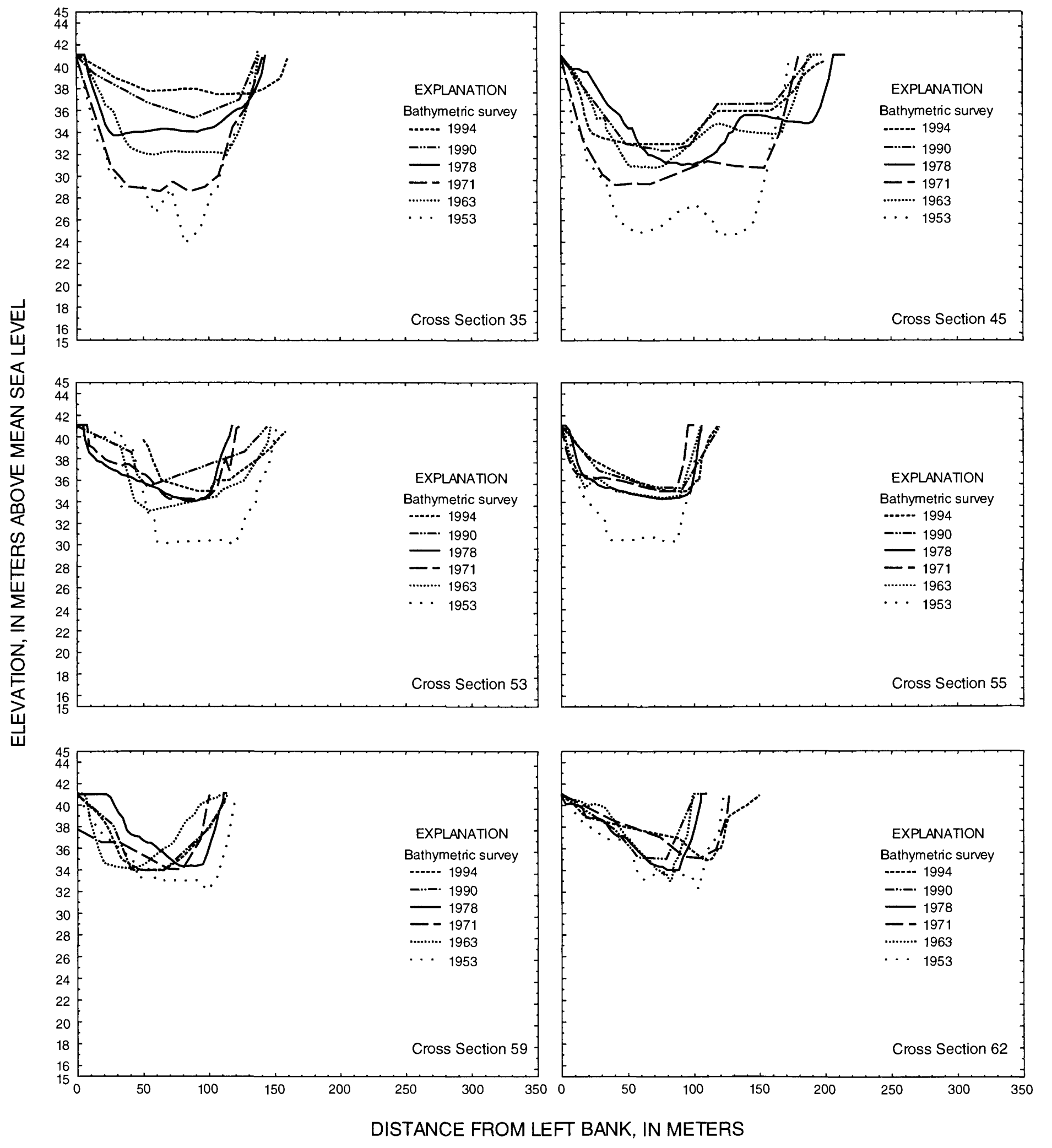

Figure 6. Historical cross sections of Lago Loíza, Puerto Rico, 1953-94. Locations of cross sections shown on figure $5-$ Continued. 


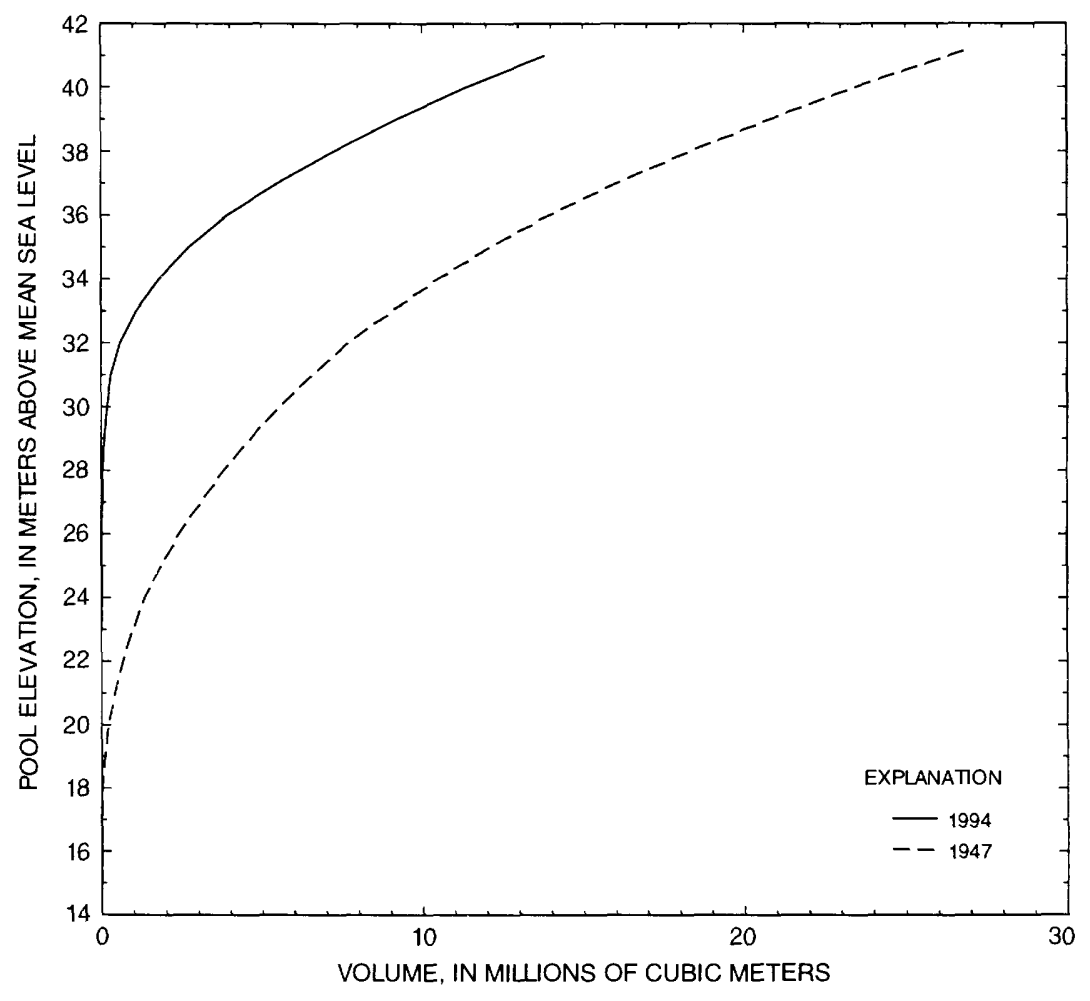

Figure 7. Stage-volume curves for Lago Loíza, Puerto Rico. The curves were determined based on hydrographic data collected in November 1994 and topographic data of the reservoir site collected in 1947.

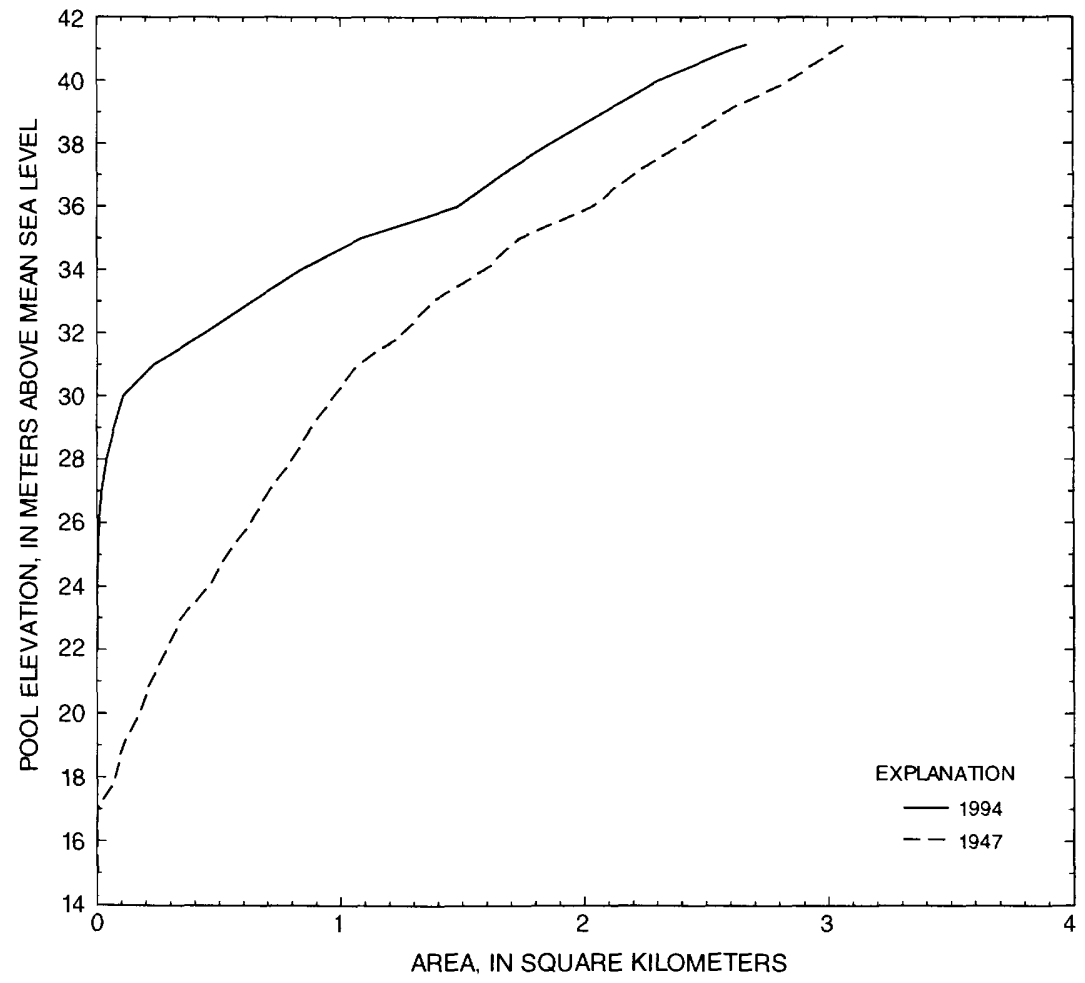

Figure 8. Stage-area curves for Lago Loíza, Puerto Rico. The curves were determined based on hydrographic data collected in November 1994 and topographic data of the reservoir site collected in 1947. 


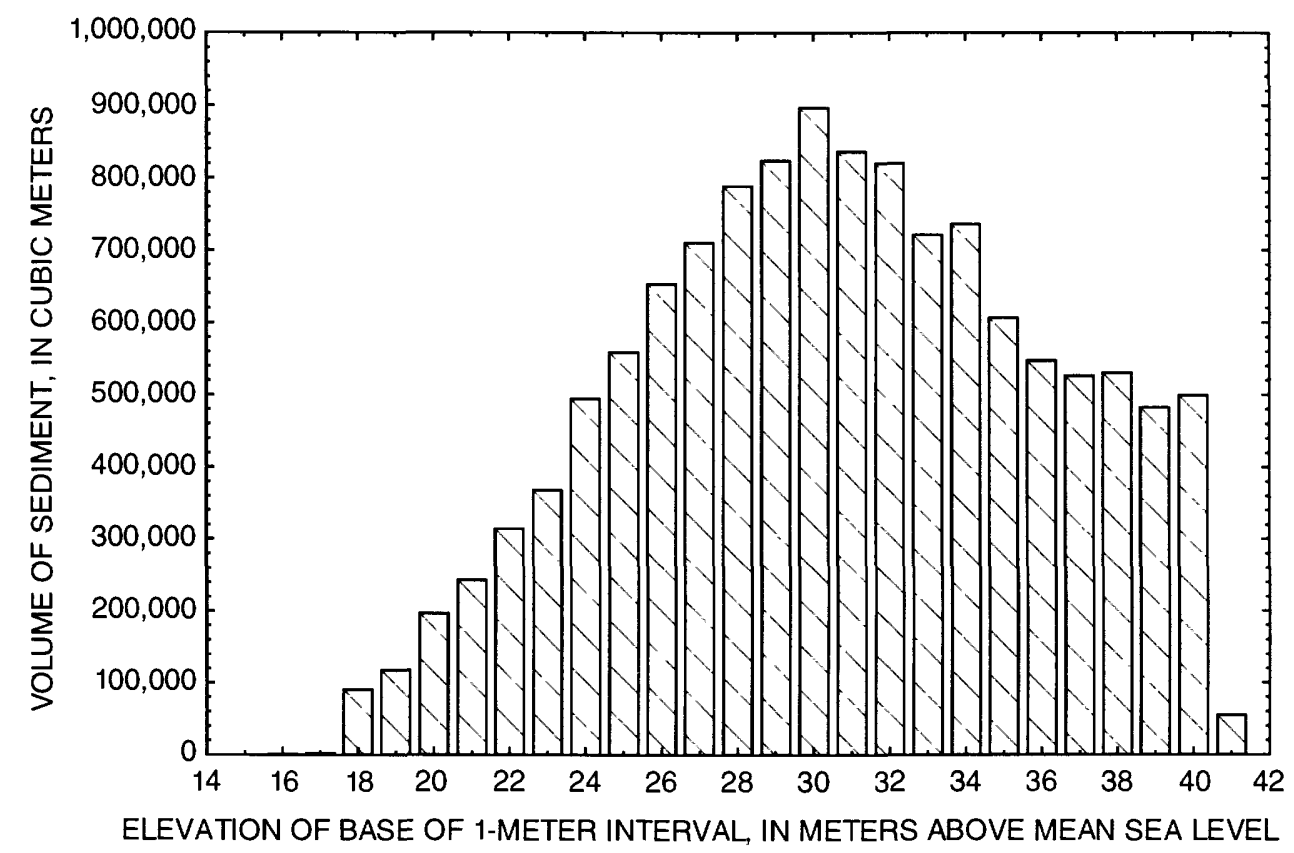

Figure 9. Volume of sediment deposited in Lago Loíza from 1953 to 1994, in 1-meter intervals.

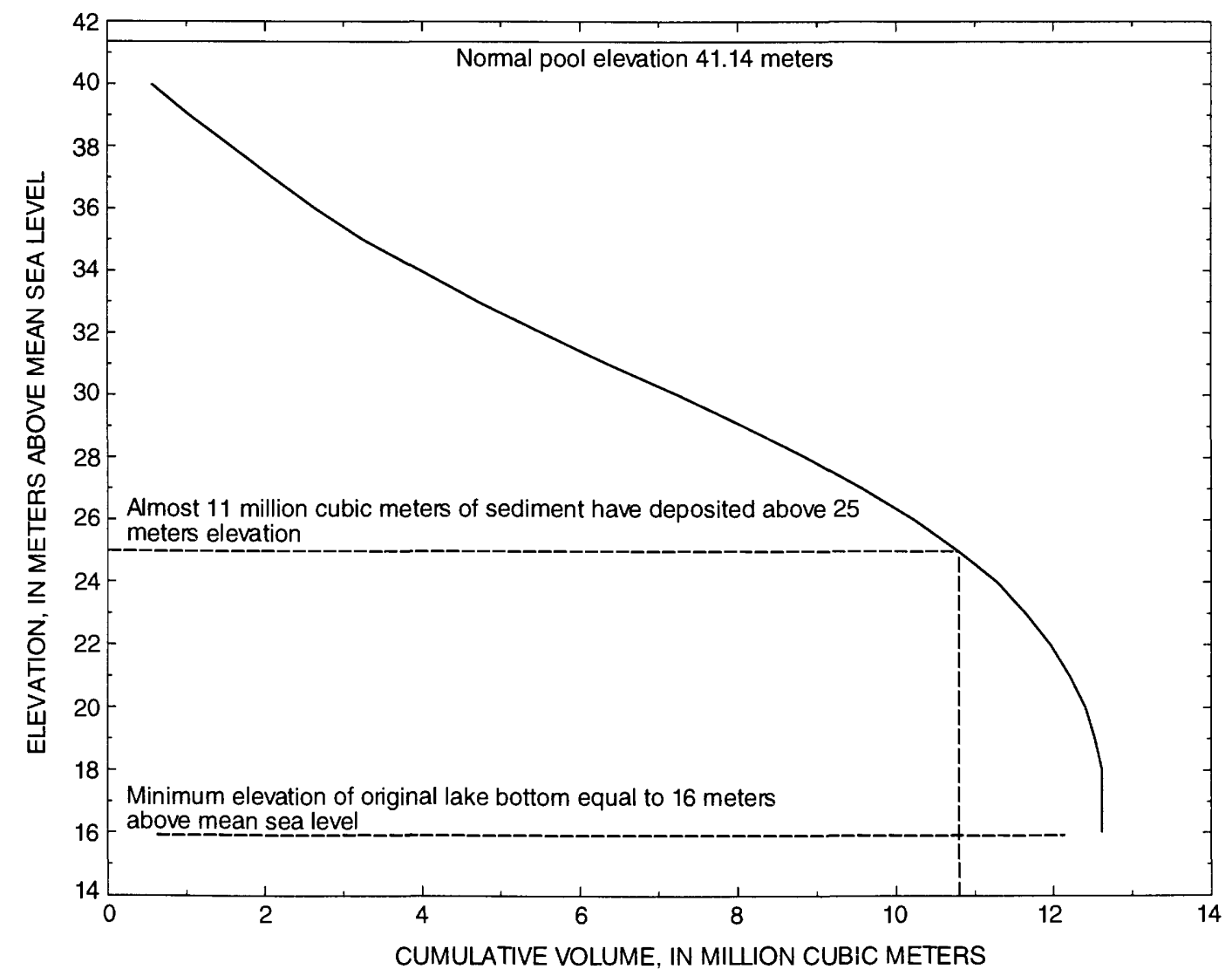

Figure 10. Total volume of sediments accumulated in Lago Loíza above a given elevation for the period 1953 to 1994. 


\section{REFERENCES}

Blanton, J.O., III., 1982, Procedures for monitoring reservoir sedimentation: Technical Guideline for Bureau of Reclamation, October 1982, 40 p.

Calvesbert, R.J., 1970, Climate of Puerto Rico and U.S. Virgin Islands: U.S. Department of Commerce, Environmental Science Services Administration, 29 p.

Department of Commerce, 1991, Summary population and housing characteristics. Puerto Rico: 1990 Census of Population and Housing, Bureau of the Census Report $1990 \mathrm{CPH}-1-53,199 \mathrm{p}$.

Díaz, P.L., Aquino, Zaida, Figueroa-Alamo, Carlos, Vachier, R.J., and Sánchez, A.V., 1994, Water resources data, Puerto Rico and the U.S. Virgin Islands, Water Year 1994: U.S. Geological Survey Water-Data Report PR-94-1, 516 p.

Environmental Systems Research Institute, Inc., 1992, Surface modeling with TIN, Surface analysis and display: Environmental Systems Research Institute, Inc., Redlands, CA. U.S.A., 8 chapters (237 p.).

Gregory L. Morris \& Associates, 1992, Analysis and modeling of sediment management at Loíza Reservoir, Puerto Rico: Report prepared for Puerto Rico Aqueduct and Sewer Authority, May 1992, 57 p.

Heinemann, H.G., and Dvorak,V.I., 1963, Improved volumetric survey and computation procedures for small reservoirs: U.S. Department of Agriculture Miscellaneous Publication 970, Symposium 4 -Sedimentation in reservoirs, p. 845-856.
Hunt, J.L., 1976, Sedimentation of Loíza Reservoir, Puerto Rico: U.S. Department of Agriculture Soil Conservation Service Report SCS-TP-153, 19 p.

Iivari. T.A., 1981, A resurvey of sediment deposits in Loíza Reservoir. Puerto Rico: Prepared for the Puerto Rico Aqueduct and Sewer Authority by the U.S. Department of Agriculture. Soil Conservation Service, June 1981, $22 \mathrm{p}$.

Quiñones, Ferdinand, Green, Bruce, and Santiago, Luis, 1989. Sedimentation Survey of Lago Loíza, Puerto Rico, July 1985: U.S. Geological Survey WaterResources Investigations Report 87-4019, 17 p.

Puerto Rico Electric Power Authority, 1980, Phase I Inspection Report: National Dam Safety Program, 1978-79.

Sheda, H.E., and Legas, James., 1968, Condition of Concrete Dams in Puerto Rico: Section 15, Condition of Loíza Dam, Puerto Rico: Prepared for Puerto Rico Water Resources Authority, Puerto Rico Aqueduct and Sewer Authority by the U.S. Department of Interior. Bureau of Reclamation, 14 p., 11 pls. 


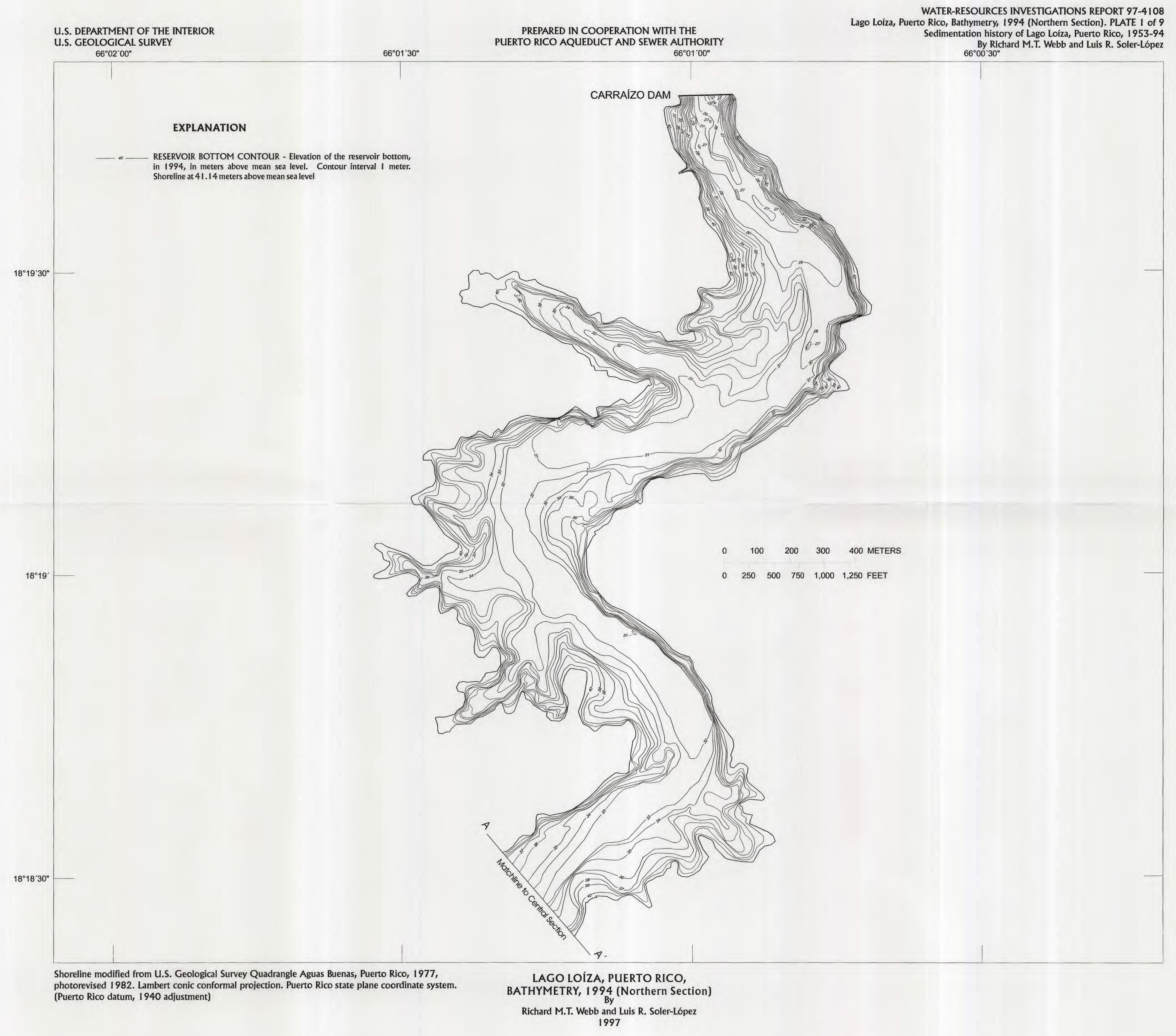




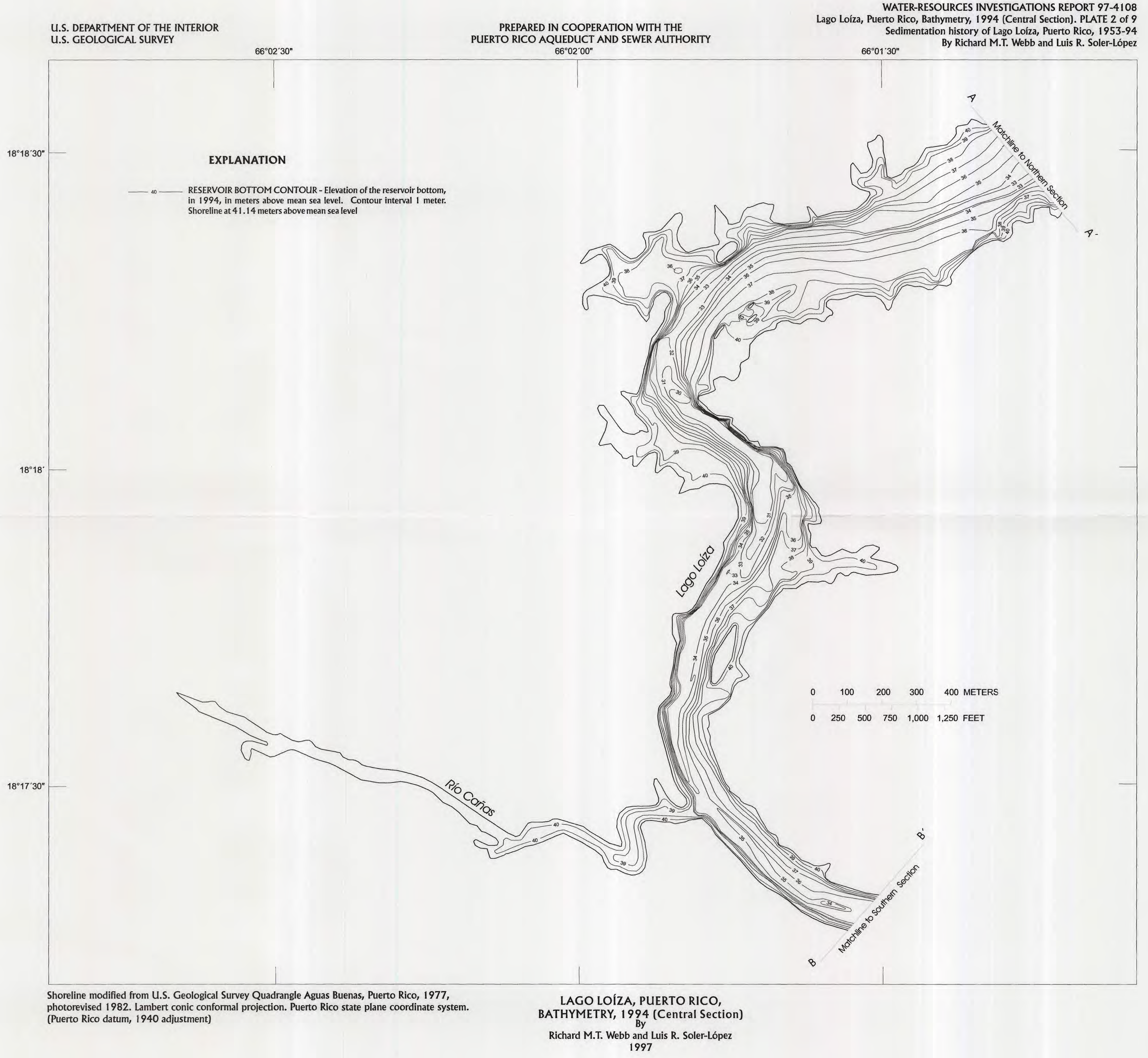




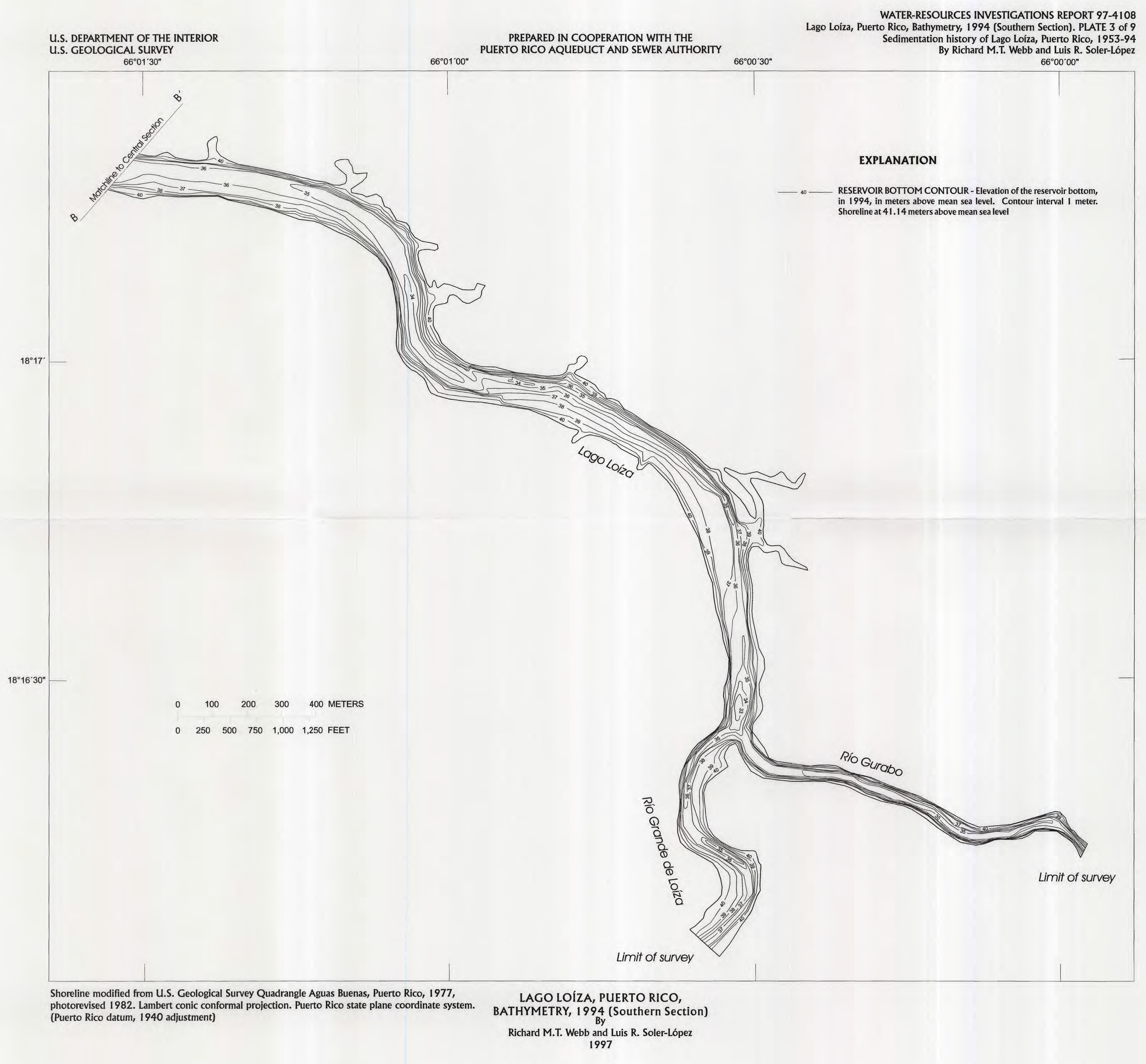




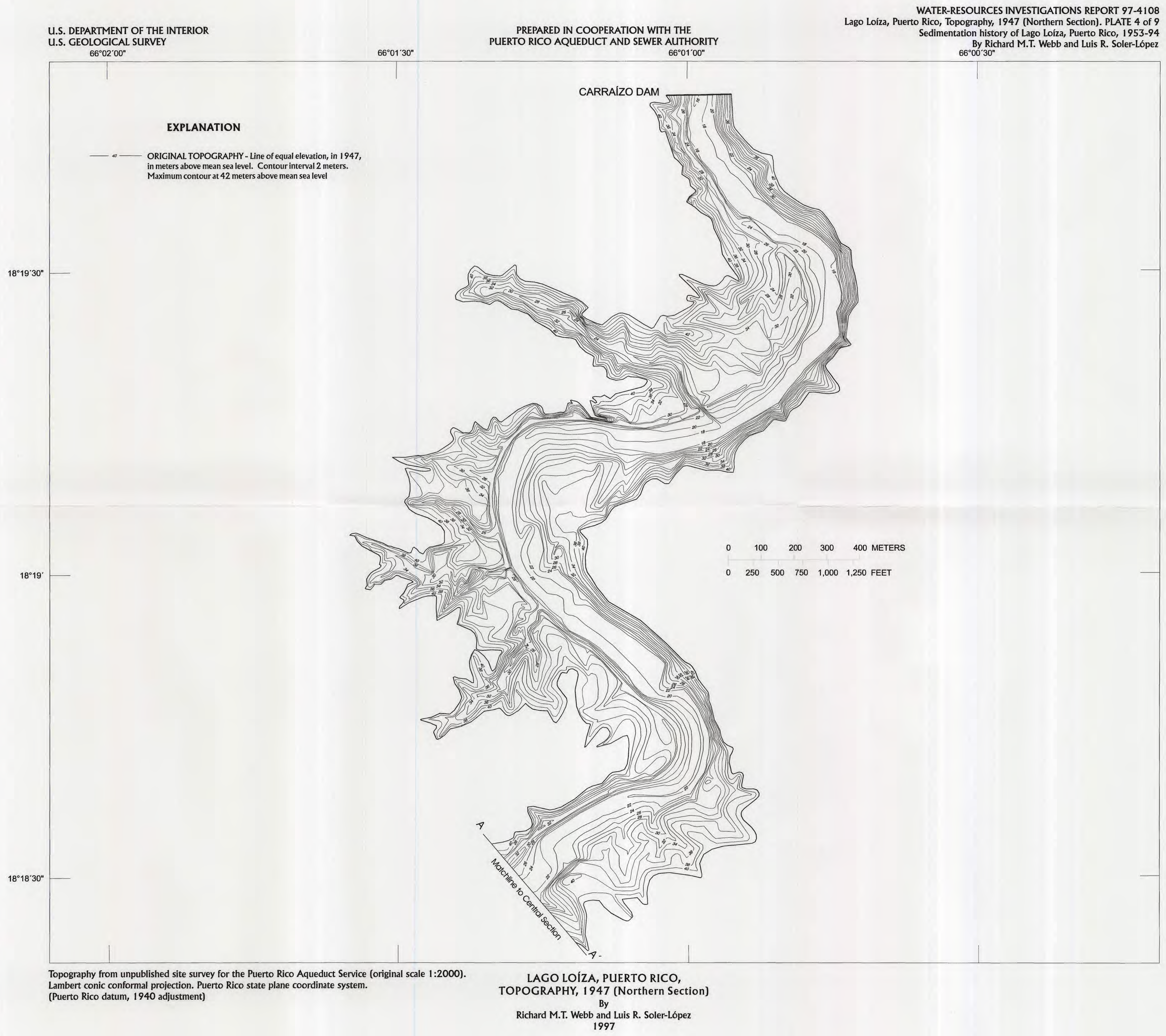




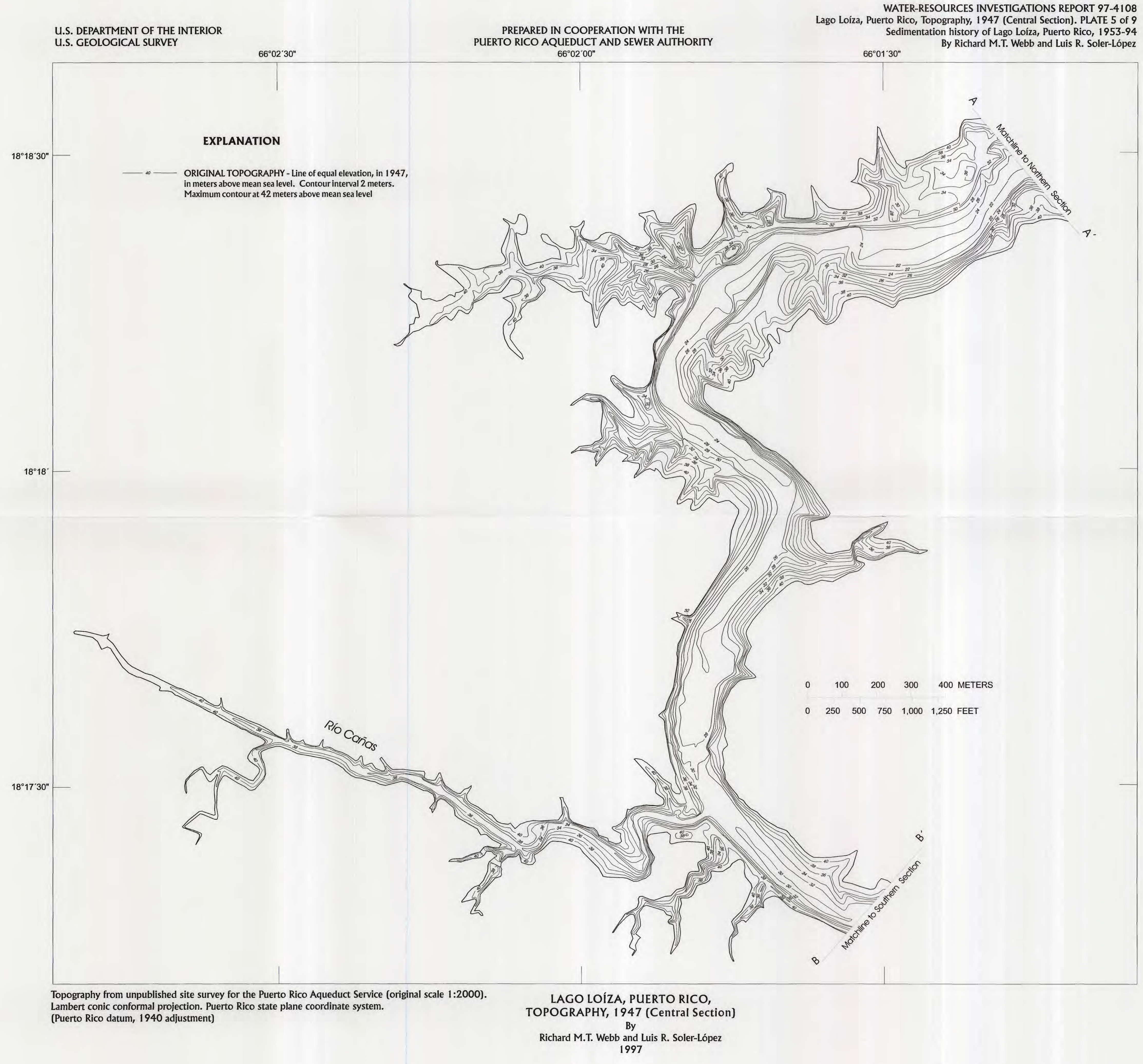




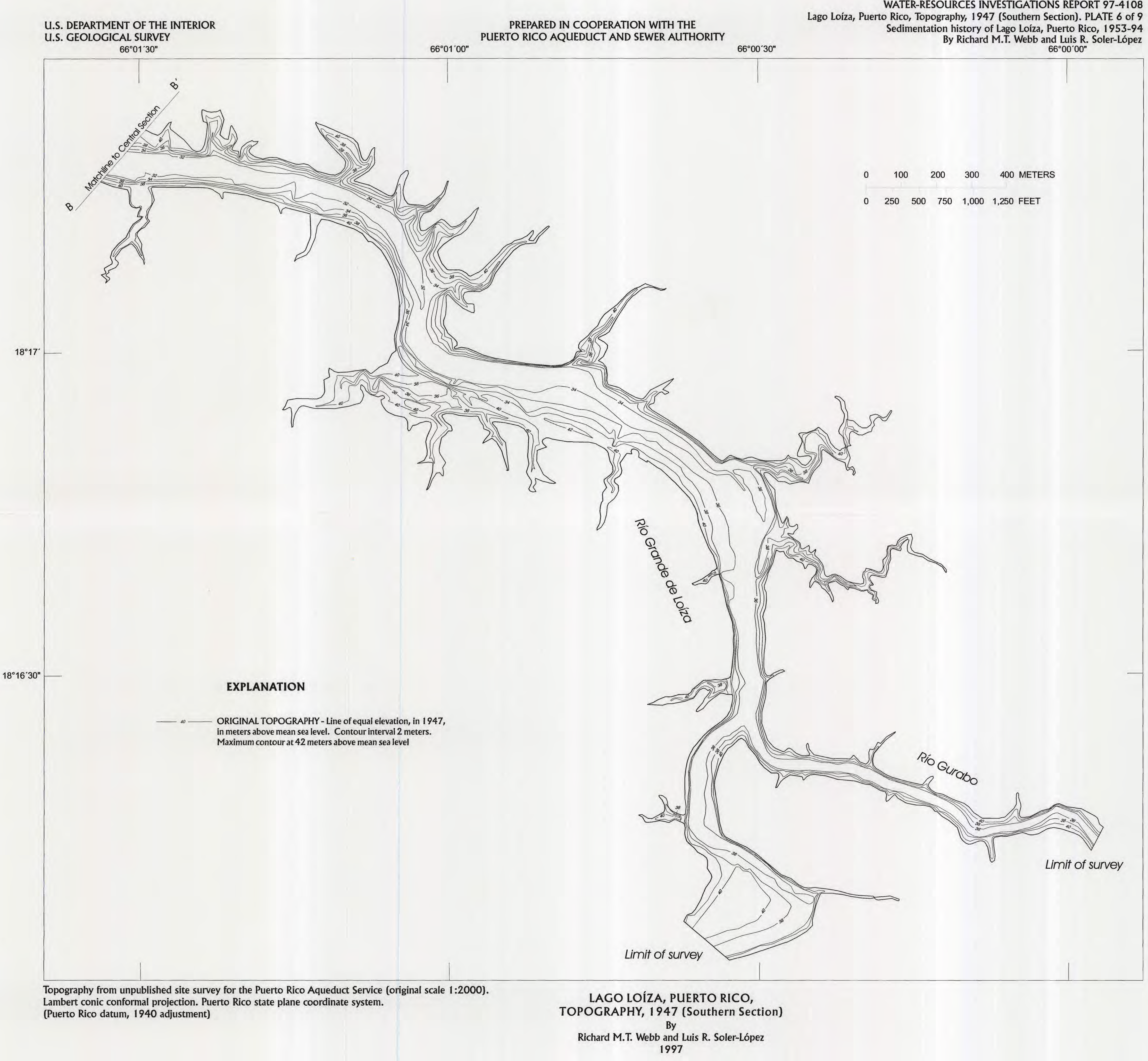


U.S. DEPARTMENT OF THE INTERIOR ${ }_{66}^{\circ} 0^{\circ} 00^{\prime \prime}$
REPARED IN COOPERATION WITH THE PUERTO RICO AQUEDUCT AND SEWER AUTHORITT

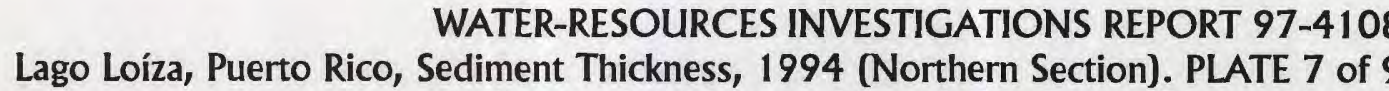
Sedimentation history of Lago Loiza, Puerto Rico, 1953-94
By Richard M.T. Webb and Luis R. Soler-Lopez

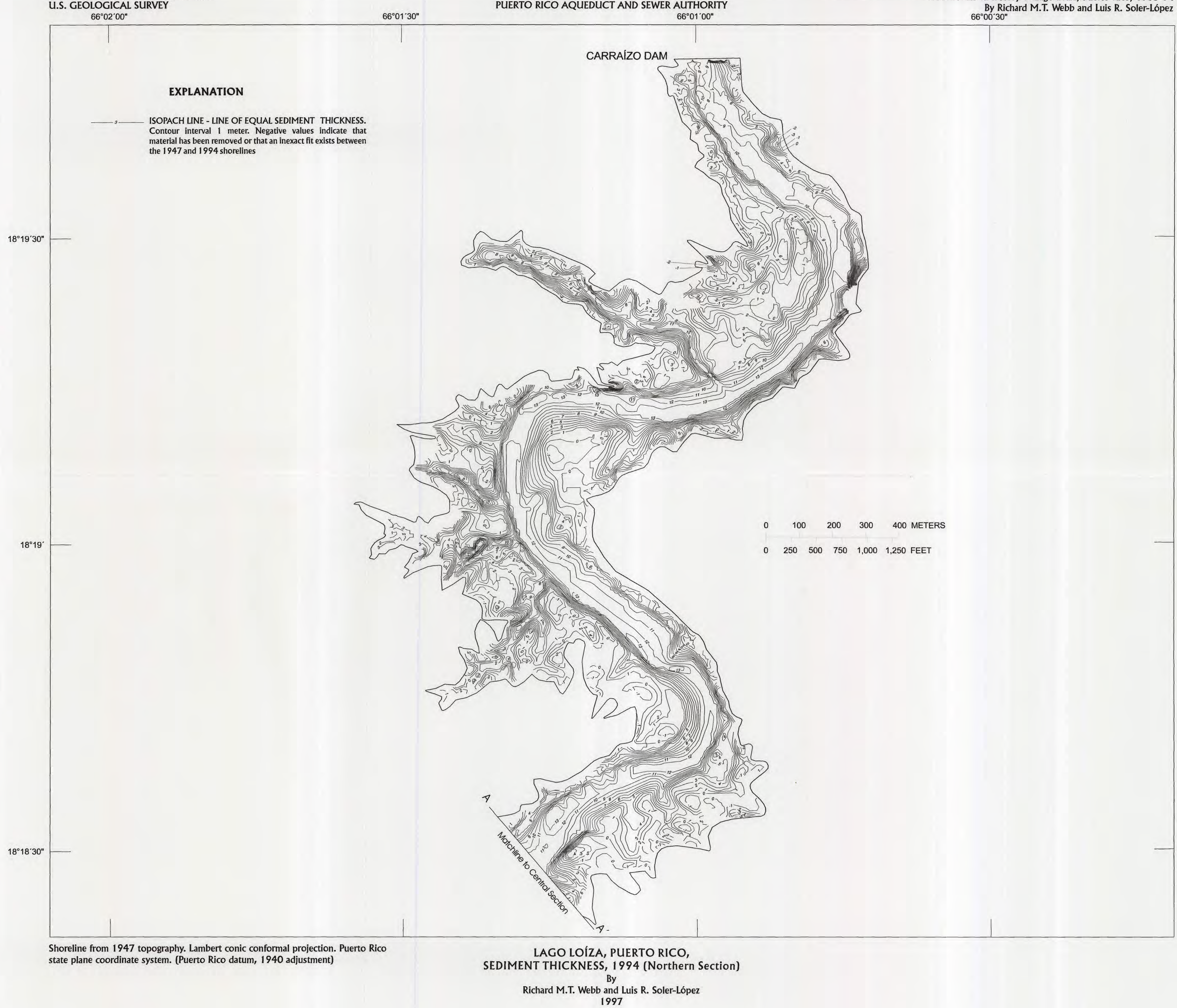




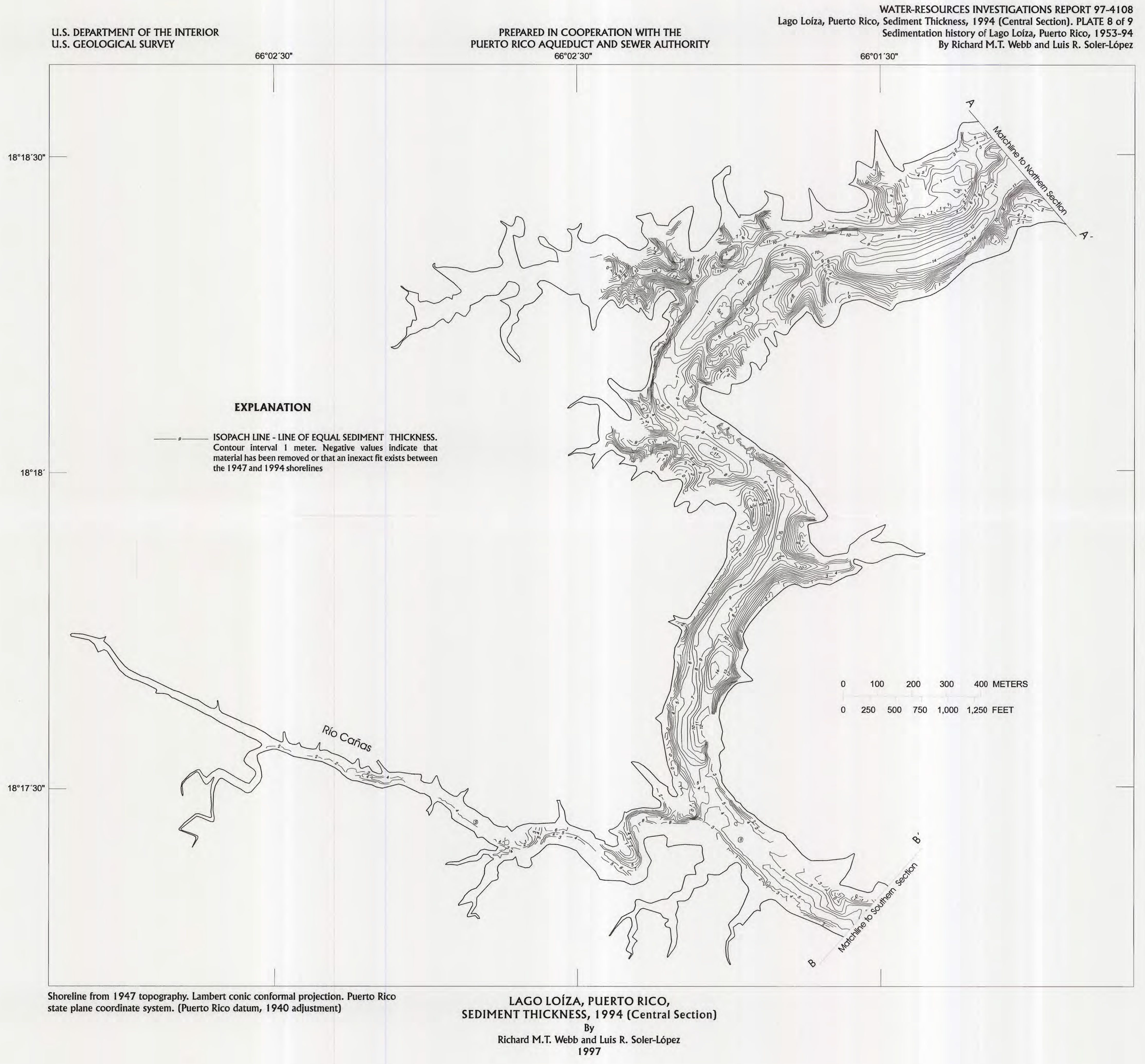




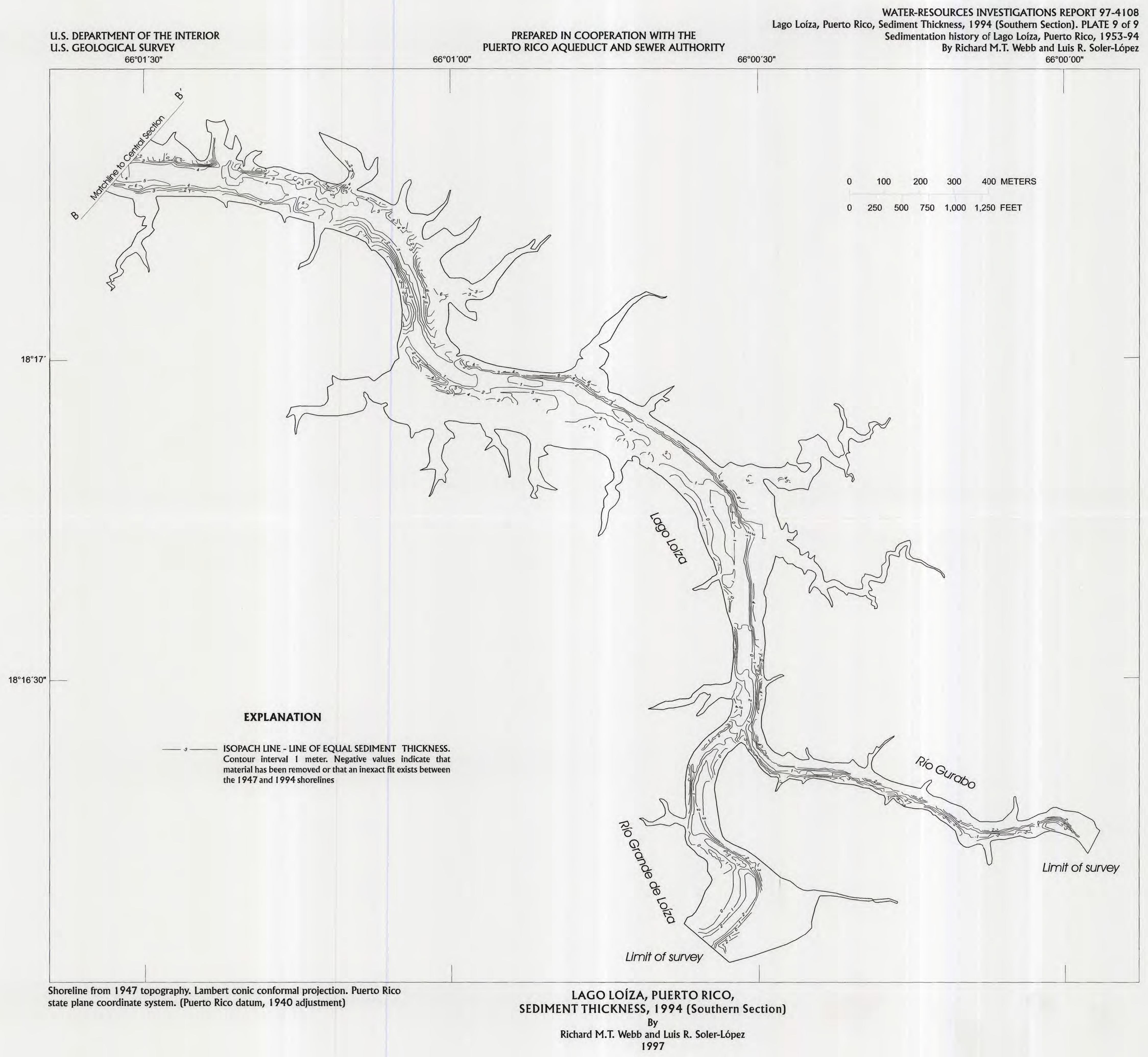

